\title{
The Role of Adaptogens in Prophylaxis and Treatment of Viral Respiratory Infections
}

\author{
Alexander Panossian 1,2,*(D) and Thomas Brendler ${ }^{3,4,5}$ (D) \\ 1 Phytomed AB, Vaxtorp, 31275 Halland, Sweden \\ 2 EuropharmaUSA, Green Bay, WI 54311, USA \\ 3 Department of Botany and Plant Biotechnology, University of Johannesburg, \\ Johannesburg 2000, South Africa; txb@plantaphile.eu \\ 4 Traditional Medicinals Inc., Rohnert Park, CA 94928, USA \\ 5 Plantaphile, Collingswood, NJ 08108, USA \\ * Correspondence: ap@phytomed.se
}

Received: 20 August 2020; Accepted: 3 September 2020; Published: 8 September 2020

check for updates

\begin{abstract}
The aim of our review is to demonstrate the potential of herbal preparations, specifically adaptogens for prevention and treatment of respiratory infections, as well as convalescence, specifically through supporting a challenged immune system, increasing resistance to viral infection, inhibiting severe inflammatory progression, and driving effective recovery. The evidence from pre-clinical and clinical studies with Andrographis paniculata, Eleutherococcus senticosus, Glycyrrhiza spp., Panax spp., Rhodiola rosea, Schisandra chinensis, Withania somnifera, their combination products and melatonin suggests that adaptogens can be useful in prophylaxis and treatment of viral infections at all stages of progression of inflammation as well as in aiding recovery of the organism by (i) modulating innate and adaptive immunity, (ii) anti-inflammatory activity, (iii) detoxification and repair of oxidative stress-induced damage in compromised cells, (iv) direct antiviral effects of inhibiting viral docking or replication, and (v) improving quality of life during convalescence.
\end{abstract}

Keywords: adaptogens; Andrographis; Eleutherococcus; Glycyrrhiza; Panax; Rhodiola; Schisandra; Withania; melatonin; viral infection

\section{Introduction}

The COVID-19 pandemic brought new challenges to biomedical sciences, specifically, the development of effective therapeutics for prevention and treatment of acute viral and stress-induced diseases. Unfortunately, the potential of herbal preparations in prevention and treatment of viral infections is underestimated. Lack of solid evidence for efficacy and safety from randomized, controlled clinical studies is often cited as a reason for dismissal. In reality, the risk of adverse events is significantly higher for synthetic antiviral and immunotropic drugs than for the vast majority of herbal preparations. The COVID-19 pandemic, for which to date no cure or vaccine exist, thus provides a more than timely context in terms of findings related to epidemiology and pathogenesis in which to discuss relevant evidence from pre-clinical and clinical studies of herbal preparations, specifically adaptogens.

Pathogenesis and progression of a viral infection is a multistep process [1,2], which requires an appropriate therapeutic strategy starting with initiation of overall defense response to the pathogen [3-6]. Included in this process are numerous extra- and intracellular interactions between components of host defense and life cycle regulation systems on all levels of regulation-genomic, transcriptomic, proteomic, metabolomic and macrobiotic [7]. Consequently, effective prevention or treatment of a viral infection and other viral infections requires pharmaceutical intervention affecting the innate and adaptive immune system, phases I-III metabolizing enzymes of detoxifying and repair systems, 
as well as the virus' life cycle and proliferation (Figure 1). This can be achieved with herbal preparations that have polyvalent and pleiotropic actions on host defense systems. For instance, it was found that more than half of SARS-CoV-2-infected subjects were asymptomatic at the time of testing [8], which points at the ability of the innate immune system to curb progression of COVID-19 at an early stage of invasion of the pathogen. Both activation and inhibition of various components of innate immune system $[4,5,9]$ by numerous natural compounds of plant kingdom is well documented in many publications. Specifically, complex mixtures of natural compounds (or herbal extracts) synergistically targeting multiple elements of molecular networks involved in inflammatory defense response are presumably more effective than mono-drugs that target only one receptor $[10,11]$.

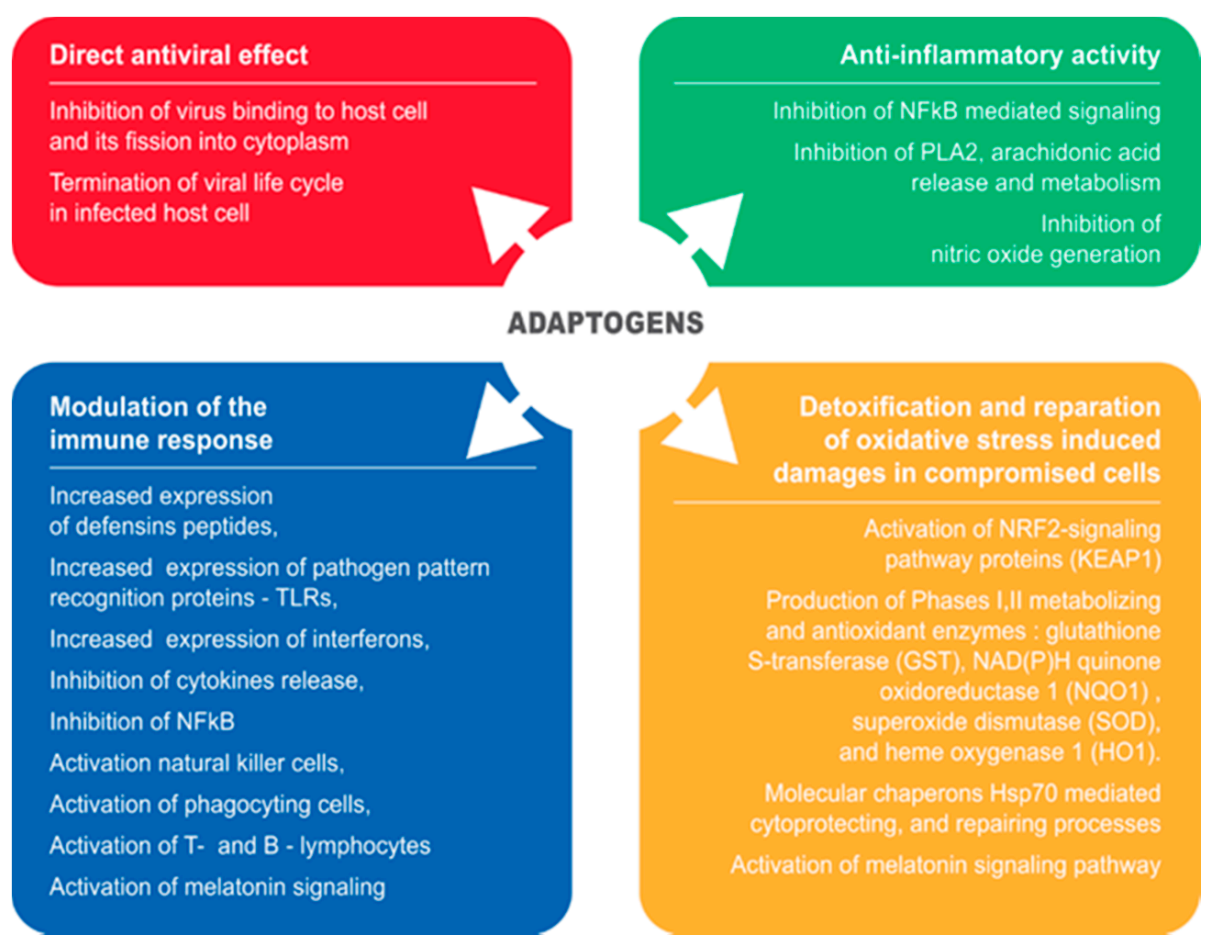

Figure 1. Schematic diagram of reported effects of adaptogenic plants elucidated in animal and cell culture models: (i) modulatory effects on immune response (blue block), (ii) anti-inflammatory activity (green bock), (iii) detoxification and repair of oxidative stress-induced damage in compromised cells (brown block), and (iv) direct antiviral effect via infraction with viral docking or replication (red block).

Adaptogens are natural stress-protective compounds or plant extracts that increase adaptability, resilience, and survival of organisms [12]. Adaptogens increase "the state of non-specific resistance" of organisms [13] to harm [14,15], including bacterial and viral pathogens. Non-specific defense responses to pathogens depend on the body's ability to recognize conserved features of pathogens by the evolutionarily ancient innate immune system, a group of proteins and phagocytic cells, which become activated during the critical first hours and days of infection to destroy invaders [9]. The basic mechanisms of innate immune responses that regulate innate defense, e.g., pattern recognition by toll-like receptors (TLR), defensins, etc., are conserved and apparently involved in innate immunity in all multicellular organisms. Their conservation during evolution shows the importance of innate responses in the defense against microbial and viral pathogens [9]. 
More than 100 medicinal plants have been reported to have adaptogenic activity, however only few, i.e.,

- Andrographis paniculata (Burm. F.) Wall. ex. Nees, Acanthaceae (AP),

- Eleutherococcus senticosus (Rupr. \& Maxim.) Maxim, Araliaceae (ES),

- Glycyrrhiza spp., Fabaceae (GS),

- Panax spp., Araliaceae (PS),

- Rhodiola rosea L., Crassulaceae (RR),

- $\quad$ Schisandra chinensis (Turcz.) Bail., Schisandraceae (SC), and

- Withania somnifera (L.) Dunal, Solanaceae (WS)

Comply with the key criterium, that is to exhibit multitarget effects on the neuroendocrine-immune system by triggering adaptive stress responses. These include stimulation of cellular and organismal defense systems, activation of intracellular and extracellular adaptive signaling pathways, and expression of stress-activated proteins to change protection or repair capacity and increase non-specific resistance and adaptation to stress [11,12].

Anti-inflammatory, antiviral, antioxidant and other related activity of plants referred to as adaptogenic have been demonstrated in numerous pre-clinical studies. Tables 1-5 and Figure 1 show multiple molecular targets identified for adaptogenic plant extracts exhibiting:

- Specific antiviral action-preventing viruses binding to host cells, and on non-structural (Nsps) and structural proteins involved in viral life cycle in infected host cells and replication of the virus;

- Non-specific antiviral action by the effects on:

O Innate immunity including activation of defensins, the complement system, upregulation of expression of pathogen's pattern recognition receptors, specifically TLR, and interferons;

O Downregulation of expression of pro-inflammatory cytokines IL-1, IL2, IL-6, IL-8, and TNF, activation of natural killer cells, mucous sentinel and phagocyting cells (mast cells, dendritic cells, macrophages, neutrophils, eosinophils, and basophils) and the melatonin signaling pathways;

O Adaptive immunity including T cells and MHC proteins, B cells and antibodies.

- Anti-inflammatory activity by inhibition of:

○ Release of arachidonic acid from membrane phospholipids following conversion into COX-2 and lipoxygenase-mediated pro-inflammatory metabolites such as prostaglandins, thromboxane B2, leukotrienes, as well as platelet-activating factor;

O Inducible NO synthase;

○ NF-kB-mediated pro-inflammatory signaling pathways.

- Detoxifying and cytoprotectant activity in oxidative stress-induced injuries of compromised cells and tissues:

O Activation of the NRF2-mediated oxidative stress response signaling pathway regulated production of chaperons and stress response proteins, activity of phase I and II metabolizing enzymes, phase III detoxifying proteins, proteasomal degradation proteins, antioxidant proteins (superoxide dismutase (SOD), glutathione S-transferase (GST), NAD(P)H quinone oxidoreductase 1 (NQO1) and heme oxygenase 1 (HO1);

$\bigcirc$ Activation of expression and release of molecular chaperons Hsp70, which mediate cytoprotectant and repair processes;

- Activation of the melatonin signaling pathways. 
Key elements of innate immunity stimulation are activation of first-line defense response IF- $\gamma$ and TLR followed by inhibition of NF-KB and inflammation mediated by proinflammatory cytokines. Adaptogens activate adaptive signaling pathways by upregulating gene expression-encoding phosphatidylinositol 3-kinase (PI3K), protein kinase C (PKC), and mitogen-activated protein kinases (MAPKs) [11], which are upstream of transcription factors (Nrf2, HNF1, CCAAT, C/EBP $\beta$, and PXR), FXR and peroxisome proliferator-activated receptors that promote the induction of phase II enzymes and phase III transporters involved in metabolic detoxification process, clearance of breakdown products [16] and overall defense response to pathogens. Therapeutically important features of adaptogenic activity are beneficial effects on detoxification, and repair processes, leading to recovery and increased survival in virus-induced oxidative stress, key to which are activation of the antioxidant NRf2-signalling pathway, the production of detoxification enzymes, molecular chaperons Hsp70 and the melatonin signaling pathway for regulation of homeostasis (Tables 3 and 4).

The search for anti-SARS-CoV-2 therapeutics focuses on both structural and functional viral proteins. Sixteen non-structural proteins (Nsps 1-16) are involved in RNA transcription, translation, protein synthesis, processing and modification, virus replication and infection of the host [17]. They are considered virus-specific molecular targets for pharmacotherapeutic intervention [17-23] for a number of reasons:

- $\quad$-terminal gene 1 protein (Nsp1) suppresses host innate immune response, inhibiting type-I interferon production and induces host mRNA degradation [24];

- Nsp3 (papain-like protease, PLpro) is essential for virus replication and to antagonize the host's innate immunity;

- Nsp5 (3-chimotrypsin-like protease, 3CLpro) mediates viral replication, transcription and the maturation of Nsps, which is essential in the life cycle of the virus;

- Nsp12 (PNA-dependent PNA polymerase enzyme, RdRp) is a conserved vital enzyme of the coronavirus replication/transcription complex;

- Nsp13 (helicase enzyme) is a multifunctional protein necessary for the replication of coronavirus.

Nine structural and accessory proteins, including spike (S) and envelope (E) glycoproteins, membrane $(\mathrm{M})$ and nucleocapsid $(\mathrm{N})$ proteins, are probably most important in the search for inhibitors of their expression or functions [19]. The primary function of structural S proteins is to bind the S1 subunit with the host cell surface receptor, angiotensin-converting enzyme 2 (ACE2), and the S2 subunit with serine protease TMPRSS2, which mediates virus-cell and cell-cell membrane fusion. ACE2 has been identified as a functional receptor playing a crucial role in SARS coronavirus-induced lung injury $[25,26]$. ACE2 is expressed in all tissues-particularly in pulmonary and heart tissues, where it is significantly increased in hypertensive patients continuously using ACE inhibitors and angiotensin 1 receptor (AT1R) blockers. This explains the higher death rate in elderly individuals with comorbidities such as hypertension, diabetes, and heart disease [27-30].

\section{Results}

\subsection{Pre-Clinical Investigations}

We have organized results of pre-clinical investigations into five groups: direct viricidal effects, specific antiviral actions, non-specific antiviral actions, anti-inflammatory effects and repair of oxidative stress-induced injuries in compromised cells and tissues, and other effects of potential relevance in the progression of viral infections. Outcomes are presented in Tables 1-5. They include results for aforementioned adaptogenic plant extracts and some of their active constituents: tetracyclic and pentacyclic triterpene glycosides (ginsenosides, withanolides, and glycyrrhizin), diterpene lactones (andrographolides), phenethyl- and phenylpropanoid glycosides (salidroside, rosavin, and eleutheroside B), and lignans (eleutheroside E, schisandrins, anwulignan, and ellagic acids). 
Table 1. Direct viricidal effects.

\begin{tabular}{|c|c|c|c|c|c|c|c|}
\hline Virus & $\begin{array}{c}\text { AP } \\
\text { Andrographolides }\end{array}$ & $\begin{array}{c}\text { ES } \\
\text { Eleutherosides }\end{array}$ & $\begin{array}{l}\text { GS } \\
\text { Glycyrrhizin and } \\
\text { Glycyrrhizic Acid }\end{array}$ & $\begin{array}{c}\text { PS } \\
\text { Ginsenosides }\end{array}$ & $\begin{array}{c}\text { RR } \\
\text { Salidroside, } \\
\text { Rosavin, Ellagic } \\
\text { and Gallic Acids }\end{array}$ & $\begin{array}{c}\text { SC } \\
\text { Schisandrins and } \\
\text { Anwulignan }\end{array}$ & $\begin{array}{c}\text { WS } \\
\text { Withanolides }\end{array}$ \\
\hline SARS-related coronavirus & & & [31-33] & & & & \\
\hline $\begin{array}{l}\text { Ebola virus (EBOV) and } \\
\text { Marburg virus (MARV) }\end{array}$ & & & & & [34] & & \\
\hline Human rhinovirus (HRV) & & [35] & & & & & \\
\hline $\begin{array}{l}\text { Respiratory syncytial } \\
\text { virus (RSV) }\end{array}$ & & [35] & [36] & [37] & & & \\
\hline H1N1 influenza A virus & [38-40] & {$[35,41-44]$} & {$[40,45]$} & {$[46-53]$} & [54] & & \\
\hline H2N2 influenza virus & & & [55] & & & & \\
\hline H3N2 influenza virus & & & & {$[50,53,56]$} & & & \\
\hline H5N1 avian influenza virus & [57] & & [58] & {$[50,56]$} & [34] & & \\
\hline H7N9 influenza & & & & [50] & & & \\
\hline H9N2 avian influenza virus & & & & & [54] & & \\
\hline Chikungunya virus & [59-61] & & & & & & \\
\hline Dengue virus & {$[59,60]$} & & & & [62] & & \\
\hline Coxsackievirus B3 & & & & & [63] & & [64] \\
\hline
\end{tabular}


Table 2. Specific antiviral actions/effects on SARS virus docking and replication.

\begin{tabular}{|c|c|c|c|c|c|c|c|}
\hline Target/Mediator & $\begin{array}{c}\text { AP } \\
\text { Andrographolides }\end{array}$ & $\begin{array}{c}\text { ES } \\
\text { Eleutherosides }\end{array}$ & $\begin{array}{c}\text { GS } \\
\text { Glycyrrhizin and } \\
\text { Glycyrrhizic Acid }\end{array}$ & $\begin{array}{c}\text { PS } \\
\text { Ginsenosides }\end{array}$ & $\begin{array}{c}\text { RR } \\
\text { Salidroside, } \\
\text { Rosavin, Ellagic } \\
\text { and Gallic Acids }\end{array}$ & $\begin{array}{c}\text { SC } \\
\text { Schisandrins and } \\
\text { Anwulignan }\end{array}$ & $\begin{array}{c}\text { WS } \\
\text { Withanolides }\end{array}$ \\
\hline \multicolumn{8}{|c|}{ Effects on Viral Life Cycle in Infected Host Cells-Targets Preventing the Virus RNA Synthesis and Replication } \\
\hline $\begin{array}{c}\text { Nsp5: 3-chymotrypsin-like } \\
\text { protease (3Clpro)-main } \\
\text { protease of SARS-CoV-2 (Mpro) }\end{array}$ & {$[22,65]$} & {$[19,66]$} & & {$[19,66]$} & {$[19,66]$} & {$[19,66]$} & \\
\hline $\begin{array}{l}\text { Nsp3: Papain-like } \\
\text { protease (Plpro) }\end{array}$ & [22] & {$[19,66]$} & & {$[19,66]$} & {$[19,66]$} & {$[19,66]$} & \\
\hline $\begin{array}{l}\text { Nsp12: RNA-dependent RNA } \\
\text { polymerase (RdRp) }\end{array}$ & [22] & & & & & & \\
\hline $\begin{array}{l}\text { Nsp1: The most } \mathrm{N} \text {-terminal } \\
\text { gene } 1 \text { protein }\end{array}$ & [22] & & & & & & \\
\hline \multicolumn{8}{|c|}{ Targets Inhibiting Virus Structural Proteins } \\
\hline $\begin{array}{l}\text { S1: Spike glycoprotein binding } \\
\text { SARS-CoV-2 to human } \\
\text { angiotensin-converting enzyme } \\
2 \text { (ACE2) of host cells }\end{array}$ & & & [67] & & & & \\
\hline $\begin{array}{c}\text { S2: Spike glycoprotein receptor } \\
\text { to type-II transmembrane serine } \\
\text { protease enzymes (TMPRSS2) } \\
\text { of host cells }\end{array}$ & [22] & & [67] & & & & \\
\hline $\begin{array}{l}\text { Blockage of binding viral } \\
\text { (Ebola/Marburg) surface } \\
\text { glycoproteins to host cells }\end{array}$ & & & & & [34] & & \\
\hline
\end{tabular}


Table 3. Non-specific antiviral actions/effects on innate and adaptive immunity.

\begin{tabular}{|c|c|c|c|c|c|c|c|c|}
\hline Target/Mediator & $\begin{array}{c}\text { AP } \\
\text { Andrographolides }\end{array}$ & $\begin{array}{c}\text { ES } \\
\text { Eleutherosides }\end{array}$ & $\begin{array}{c}\text { GS } \\
\text { Glycyrrhizin and } \\
\text { Glycyrrhizic Acid }\end{array}$ & $\begin{array}{c}\text { PS } \\
\text { Ginsenosides }\end{array}$ & $\begin{array}{c}\text { RR } \\
\text { Salidroside, Rosavin, } \\
\text { Ellagic and Gallic Acids }\end{array}$ & $\begin{array}{c}\text { SC } \\
\text { Schisandrins and } \\
\text { Anwulignan }\end{array}$ & $\begin{array}{c}\text { WS } \\
\text { Withanolides }\end{array}$ & Melatonin \\
\hline \multicolumn{9}{|c|}{ Innate Immunity } \\
\hline $\begin{array}{l}\text { Defensins: Human } \\
\beta \text {-defensin-2 }\end{array}$ & {$[68,69]$} & & & & & & & \\
\hline $\begin{array}{l}\text { Pathogen's pattern } \\
\text { recognition via TLR }\end{array}$ & {$[70,71]$} & {$[11,72]$} & {$[67,73-77]$} & [78-83] & {$[11,84,85]$} & {$[11,86-88]$} & {$[11,89]$} & [90-94] \\
\hline Interferons & [95] & [96-102] & {$[33,55]$} & {$[37,46,48,49,56]$} & {$[62,63]$} & [86] & [103-106] & [90] \\
\hline Natural killer cells & & {$[97,98]$} & [58] & [46] & & & & \\
\hline $\begin{array}{l}\text { Interleukins: IL-6, } \\
\text { IL-1 } \beta, \text { IL-10, TNF, etc. }\end{array}$ & {$[95,107,108]$} & {$[108,109]$} & {$[74,77,110]$} & $\begin{array}{c}{[37,48,49,52,111,} \\
112]\end{array}$ & {$[62,63,84]$} & {$[86,110,113]$} & {$[103-106,114]$} & {$[90,92,94,115]$} \\
\hline $\begin{array}{c}\text { Melatonin signaling } \\
\text { pathways }\end{array}$ & & [11] & & & [11] & [11] & [11] & [11] \\
\hline \multicolumn{9}{|c|}{ Adaptive Immunity } \\
\hline $\begin{array}{c}\mathrm{T} \text { cells and MHC } \\
\text { proteins }\end{array}$ & & {$[97-99,116]$} & {$[33,55,58]$} & & & [86] & [103-106,117] & \\
\hline B cells and antibodies & [95] & [72] & [55] & & & & [104-106] & \\
\hline
\end{tabular}


Table 4. Anti-inflammatory effects and repair of oxidative stress-induced injuries in compromised cells and tissues.

\begin{tabular}{|c|c|c|c|c|c|c|c|c|}
\hline Target/Mediator & $\begin{array}{c}\text { AP } \\
\text { Andrographolides }\end{array}$ & $\begin{array}{c}\text { ES } \\
\text { Eleutherosides }\end{array}$ & $\begin{array}{c}\text { GS } \\
\text { Glycyrrhizin and } \\
\text { Glycyrrhizic Acid }\end{array}$ & $\begin{array}{c}\text { PS } \\
\text { Ginsenosides }\end{array}$ & $\begin{array}{c}\text { RR } \\
\text { Salidroside, Rosavin, } \\
\text { Ellagic and Gallic Acids }\end{array}$ & $\begin{array}{c}\text { SC } \\
\text { Schisandrins and } \\
\text { Anwulignan }\end{array}$ & $\begin{array}{c}\text { WS } \\
\text { Withanolides }\end{array}$ & Melatonin \\
\hline $\begin{array}{c}\text { Arachidonic acid release, } \\
\text { inhibition of } \\
\text { phospholipase } 2\end{array}$ & [118] & & [119-121] & [122-125] & [126] & [127] & [128-130] & \\
\hline COX-2-mediated signaling & {$[71,131]$} & [132] & {$[74,119,121]$} & {$[111,123,125]$} & [132] & & [132] & [132] \\
\hline $\begin{array}{l}\text { Lipoxygenase-mediated } \\
\text { signaling of arachidonic } \\
\text { acid pro- and } \\
\text { anti-inflammatory } \\
\text { metabolites leukotrienes, } \\
\text { lipoxins, resolvins, etc. }\end{array}$ & & [132] & {$[119,121]$} & & [132] & [127] & {$[130,132]$} & [132] \\
\hline $\begin{array}{l}\text { Platelet-activating factor } \\
\text { (PAF) }\end{array}$ & {$[133,134]$} & & & {$[135,136]$} & & {$[137,138]$} & [89] & \\
\hline $\begin{array}{c}\text { Nitric oxide-mediated } \\
\text { inflammation: } \\
\text { Inducible NO synthase } \\
\text { oxide catabolites (NOCs) }\end{array}$ & {$[108,139]$} & [108] & {$[32,74,108]$} & [52] & [140] & {$[88,108,140]$} & & {$[90,115]$} \\
\hline $\begin{array}{c}\text { NF-kB-mediated } \\
\text { inflammation } \\
\text { NF-kB signaling, } \\
\text { translocation and } \\
\text { expression }\end{array}$ & {$[70,71,107,141]$} & {$[72,142-150]$} & {$[74,77]$} & [151-155] & [156-163] & {$[86,87,113,164-168]$} & {$[89,114,169-172]$} & {$[90,173]$} \\
\hline $\begin{array}{l}\text { Nrf2-mediated oxidative } \\
\text { stress response signaling } \\
\text { pathway proteins: } \\
\text { Phosphatidylinositol } \\
\text { 3-kinase (PI3K), protein } \\
\text { kinase B (Akt), KEAP1, etc. } \\
\text { Nrf2-ARE (antioxidant } \\
\text { response element) } \\
\text { expression }\end{array}$ & [174-182] & [183] & [119] & {$[111,151,184-187]$} & {$[159,160,162,163,188-190]$} & {$[86,113,165,191-193]$} & [194-196] & [197] \\
\hline
\end{tabular}


Table 4. Cont

\begin{tabular}{|c|c|c|c|c|c|c|c|c|}
\hline Target/Mediator & $\begin{array}{c}\text { AP } \\
\text { Andrographolides }\end{array}$ & $\begin{array}{c}\text { ES } \\
\text { Eleutherosides }\end{array}$ & $\begin{array}{c}\text { GS } \\
\text { Glycyrrhizin and } \\
\text { Glycyrrhizic Acid }\end{array}$ & $\begin{array}{c}\text { PS } \\
\text { Ginsenosides }\end{array}$ & $\begin{array}{c}\text { RR } \\
\text { Salidroside, Rosavin, } \\
\text { Ellagic and Gallic Acids }\end{array}$ & $\begin{array}{c}\text { SC } \\
\begin{array}{c}\text { Schisandrins and } \\
\text { Anwulignan }\end{array}\end{array}$ & $\begin{array}{c}\text { WS } \\
\text { Withanolides }\end{array}$ & Melatonin \\
\hline $\begin{array}{l}\text { Antioxidant proteins (SOD, } \\
\text { GST, NQO1 and HO1), } \\
\text { lipid peroxidation }\end{array}$ & {$[176,178,182]$} & [183] & & {$[111,151,185,187,198]$} & {$[158,160,162,163,188,190]$} & {$[86,113,165,191-193]$} & {$[103,194]$} & {$[93,115,197$} \\
\hline $\begin{array}{c}\text { Molecular } \\
\text { chaperon-mediated } \\
\text { cytoprotectant and repair } \\
\text { processes Heat shock } \\
\text { proteins Hsp72 }\end{array}$ & & {$[199,200]$} & & & {$[140,199-201]$} & {$[140,199-201]$} & & \\
\hline $\begin{array}{l}\text { Melatonin signaling } \\
\text { Retinoic acid receptor } \\
\text { (RAR)-related orphan } \\
\text { nuclear receptor alpha } \\
(\operatorname{ROR} \alpha)\end{array}$ & & [11] & & & [11] & [11] & [11] & {$[11,202,203$} \\
\hline
\end{tabular}


Table 5. Other effects of potential relevance in the progression of viral infections.

\begin{tabular}{cccccccc}
\hline Activity & AP & ES & GS & PS & RR & SC & WS \\
\hline adaptogenic & {$[204,205]$} & {$[206]$} & {$[207]$} & {$[208]$} & {$[209]$} & {$[206,210-213]$} & {$[214-216]$} \\
\hline antidiabetic & {$[217-220]$} & {$[221]$} & & & & {$[212]$} & {$[214-216]$} \\
\hline antioxidant & {$[222-224]$} & {$[221]$} & {$[207]$} & {$[208]$} & {$[209]$} & {$[210,211,213]$} & {$[214-216]$} \\
\hline immunomodulatory & {$[225]$} & {$[221]$} & {$[207]$} & {$[208]$} & & {$[210,211,213]$} & {$[214-216]$} \\
\hline metabolism & & & {$[207]$} & {$[208]$} & {$[209]$} & {$[212]$} & \\
\hline gastroprotective & {$[226,227]$} & & {$[207]$} & & & {$[212]$} & \\
\hline hepatoprotective & {$[228-231]$} & {$[221]$} & {$[207]$} & {$[208]$} & & {$[210,211,213]$} & {$[214-216]$} \\
\hline cardioprotective & {$[232,233]$} & {$[221]$} & & {$[208]$} & {$[209]$} & {$[210,211,213]$} & {$[214-216]$} \\
\hline antiproliferative & {$[234-236]$} & {$[221]$} & {$[207]$} & {$[208]$} & {$[209]$} & {$[210,211,213]$} & \\
\hline neuroprotective & {$[237]$} & {$[221]$} & & {$[208]$} & {$[209]$} & {$[210,211,213]$} & {$[214-216]$} \\
\hline anti-stress/anti-fatigue & {$[238]$} & {$[221]$} & & {$[208]$} & {$[209]$} & {$[210,211,213]$} & {$[214-216]$} \\
\hline antidepressant & {$[239]$} & {$[221]$} & {$[207]$} & {$[208]$} & {$[240,241]$} & {$[212]$} & {$[214-216]$} \\
\hline
\end{tabular}

\subsection{Clinical Investigations}

\subsubsection{Andrographis paniculata}

Results of 33 RCTs (7175 patients) with AP (as a monotherapy and as fixed combinations with other herbs) clinical studies were systematically reviewed. The meta-analysis shows that AP improved cough ( $\mathrm{n}=596$, standardized mean difference SMD: $-0.39,95 \%$ confidence interval CI $[-0.67,-0.10]$ ) and sore throat. It has a statistically significant effect in improving overall symptoms of acute respiratory tract infections (ARTIs) when compared to placebo, usual care, and other herbal therapies. Evidence also suggested that AP (alone or plus usual care) shortened the duration of cough, sore throat and sick leave/time to resolution when compared versus usual care. No major adverse events (AEs) were reported, and minor AEs were mainly gastrointestinal [242].

Efficacy and safety of andrographolide-containing preparations was studied in patients with common cold in Scandinavia, South America, and India by Hancke et al. [243], Caceres et al. [244], Melchior et al. [245], and Saxena et al. [246]. These four randomized double-blind placebo-controlled trials cover in total 539 patients suffering from symptoms of common cold. Hancke et al. [243] found the efficacy and safety of AP tablets ( $1200 \mathrm{mg} /$ day) to be superior to placebo. The intensity of symptoms and signs of rhinitis, sinus pain and headache were significantly lowered compared to placebo. No adverse events were reported. Melchior et al. [245] performed a randomized, double-blind, placebo-controlled, monocenter, parallel-group trial with AP $(1020 \mathrm{mg} / \mathrm{kg})$ in 50 patients suffering from common cold over 5 days. The sick leave days were significantly reduced after the second visit in the verum group compared to placebo, the number of patients feeling recovered was increased and the number of patients experienced with easier disease was detected also to be better than placebo. Caceres et al. [244] also tested the treatment of common cold with AP (1200 mg.dat) in a randomized, double-blind, placebo-controlled, monocenter, parallel-group trial with 158 participants over 5 days. The intensity of nearly all symptoms decreased significantly in the verum group. The active treatment was clearly superior to placebo, reducing the prevalence and intensity of symptoms without observed or reported adverse effects and thus revealed a positive benefit/risk ratio. Saxena et al. [246] tested an AP extract ( $200 \mathrm{mg} /$ day, $60 \mathrm{mg}$ of andrographolide for 5 days) in a randomized, double-blind placebo-controlled clinical study involving 223 patients with uncomplicated upper respiratory tract infections. Only in the verum group all symptoms improved significantly $(p \leq 0.05)$ except earache. The overall efficacy of KalmCold ${ }^{\mathrm{TM}}$ over placebo was 2.1-fold higher $(p \leq 0.05)$ than placebo. 


\subsubsection{Eleutherococcus senticosus}

Several epidemiological studies carried out in the Soviet Union during the 1970s demonstrate that ES extract, given prophylactically, can reduce human mortality rates during the influenza epidemics as well as typical complications of an influenza infection, such as pneumonia, bronchitis, and otitis [221,247-249].

In 1986, Shadrin et al. [250] reported the results of prophylactic treatment of 1376 patients with acute respiratory illnesses during the influenza virus epidemic. Typical complications of an influenza infection, such as pneumonia, bronchitis, genyantritis and otitis, were determined in this two-parallel-group, placebo-controlled, double-blind study with a 3-month long follow-up period. A significantly lower frequency of complications caused by infections was observed in the ES group compared to the placebo group $(p<0.05)$, indicating milder infection progression. The overall morbidity rate was also consistently lower in the ES group than in the placebo group, but the differences were not statistically significant. Two consecutive open-label clinical studies of ES extract were carried out in 764 children with respiratory viral infections. The morbidity rate decreased 3.6-fold in those 396 children treated with ES liquid extract for a month. After 2 years, a 2-3-fold lower morbidity was recorded in those receiving ES liquid extract for a month compared to the control group of 252 children [251]. In a similar study with children at pre-school age, prophylactic administration of ES extract decreased the morbidity rate by $30-40 \%$ [252].

\subsubsection{Glycyrrhiza spp.}

Clinical trials conducted with GS have focused functional dyspepsia, aphthous stomatitis, gastric and duodenal ulcers, postoperative sore throat, hyperlipidemia and antiatherogenic effects [207]. Since the publication of the EMA's assessment report, numerous further clinical trials have been conducted. A recent review by Kwon et al. [253] summarizes study results related to liver, gastrointestinal, oral, skin and metabolic disorders which confirm licorice's anti-inflammatory, antioxidant, and immunomodulatory properties. However, the authors caution against chronic use, especially in patients with cardiovascular comorbidities due to the mineralocorticoid-like effect of glycyrretinic acid and GS-induced pseudoaldosteronism.

\subsubsection{Panax spp.}

PS has been extensively studied in clinical investigations of multiple adaptogenic indications [208]. Scaglione et al. [254] conducted a clinical trial of efficacy and safety of a PS extract for potentiating vaccination against the common cold and/or influenza syndrome in 227 volunteers and reported a significantly lower frequency of influenza or common cold the treatment group. The same group [255] reported significantly increased bacterial clearance in patients with chronic bronchitis who received PS extract concomitantly with antibiotic treatment. Lee et al. [256] conducted a clinical trial investigating the preventive activity of PS against acute respiratory illness (ARI) caused by viral infection in 100 volunteers and found ginseng to protect against contracting ARI, as well as decrease the duration and scores of ARI symptoms. Iqbal and Rhee [112] reviewed the evidence for antimicrobial activity of PS, specifically against pathogens causing respiratory infections from animal and in vitro models, as well as 15 clinical trials. Summarily, included investigations have shown PS to exert immunomodulatory activity, which reduces the level of proinflammatory cytokines and oxidative stress, which, in turn, reduce severity, duration, and frequency of symptoms and show potential for preventing development of respiratory infections.

\subsubsection{Rhodiola rosea}

Multiple clinicals trials on the effect of RR as a mono-product and in combinations on physical performance and stress-related fatigue have been conducted [209], affirming the traditional use as an adaptogen. Chuang et al. [257] studied the effect of RR as an adjunct treatment in patients with Chronic Obstructive Pulmonary Disease (COPD) and found it to significantly improve tidal breathing and ventilation efficiency. Zhang et al. [258] evaluated the effects of RR on the preventive treatment of 
acute lung injury (ALI) caused by post-traumatic/inflammatory and thoracic-cardiovascular operations. They observed a significant decrease in Acute Respiratory Distress Syndrome complications and concluded that early use of RR may protect against risk factors of ALI/ARDS. This recommendation was later confirmed by Lu et al. [259] in a similar trial. Ahmed et al. [260] studied the antiviral properties of $R R$ in marathon runners. RR induced antiviral activity early and delayed exercise-dependent increase in virus replication. RR's role in the treatment of ischemic heart disease was investigated by Yu et al. [261] in a meta-analysis of 13 clinical trials and found an overall positive effect on both improvement of symptoms and ECG.

\subsubsection{Schisandra chinensis}

Pre-clinical findings have been corroborated in numerous clinical investigations, specifically SC's effect in viral respiratory tract infections [212,250,262-264], by targeting viral RNA synthesis and replication and stimulating innate and adaptive immunity, among others.

\subsubsection{Withania somnifera}

Tandon and Yadav [265] reviewed 30 human clinical trials, establishing reasonable safety and efficacy in subclinical hypothyroidism; chronic stress, insomnia and anxiety; cognitive improvement; fertility; and as a chemotherapy adjuvant, among others. Adaptogenic effects were studied in three clinical trials, one of which [266] reported significantly increased oxygen consumption, maximum velocity, and average absolute and relative power under exercise conditions with WS supplementation, an outcome that may be relevant in convalescence from respiratory disease.

\subsubsection{Combination Products}

The results of five randomized, double-blind placebo-controlled studies with a fixed combination of AP and ES (Kan Jang, KJ) conducted between 1997 and 2004 in Scandinavia, South America, Russia and Armenia suggest that it relieves symptoms of uncomplicated respiratory tract infections caused by common cold [267-271] without causing any safety concerns. Caceres et al. [267] investigated the prevention of common cold in a randomized, double-blind, placebo-controlled, monocenter, parallel-group trial with 107 participants over 3 months. KJ showed a significantly reduced incidence rate of cold compared to placebo after three months. Melchior et al. [270] investigated KJ in two randomized, double-blind, placebo-controlled, monocenter, parallel-group, pilot and phase III clinical trials with correspondingly 46 and 179 participants for a maximum of 8 days (pilot study) and followed by a phase III study for 3 days in the treatment of uncomplicated upper respiratory tract infections. In the pilot study, the active therapy by Kan Jang was superior to placebo in the reduction in the total scores for all symptoms after 5 days. In the phase III study, the symptom score was more significantly improved in the treatment group compared to placebo. Gabrielian et al. [268] investigated KJ in a double-blind, placebo-controlled, multicenter, parallel-group trial in 185 participants with acute upper respiratory tract infections including sinusitis over 5 days. KJ was found to be a valuable therapeutic option and to have a positive benefit/risk ratio for the treatment of acute upper respiratory tract infections and for relief of inflammatory symptoms of sinusitis. Kulichenko et al. [269] investigated KJ in two randomized, comparator-controlled, open multicenter, parallel-group trials with 540 participants over 3 to 5 days in a pilot study, followed by a phase III study for 5 days in the treatment of uncomplicated upper respiratory infections. KJ was found to be superior in alleviation of symptoms such as headache, myalgia and conjunctivitis. Spasov et al. [271] investigated KJ in a randomized controlled three parallel-group study in 130 children with uncomplicated common cold over a period of 10 days. The amount of nasal secretion g/day and nasal congestion g/day and nasal congestion decreased significantly, and recovery time was significantly accelerated by KJ compared to Immunal and standard therapy. Kan Jang was well tolerated, and no side effects were observed in this group.

The postmarketing pharmacovigilance assessment of KJ shows a favorable benefit/risk ratio. Only 37 adverse event reports (mainly to allergic reactions) to the Swedish and Danish competent 
authorities were recorded in 23 years with over 20 million doses of $\mathrm{KJ}$ sold. This equates to one adverse event in approximately 100,000 patients, assuming an average drug uptake for 5 consecutive days [272].

\subsubsection{Activation of the Melatonin Signaling Pathway}

Another promising tool to non-specifically curb SARS-induced progression of inflammation, particularly in elderly subjects, with adaptogens is to utilize their capacity to activate the melatonin signaling pathway.

In a recent study of the molecular mechanisms of action of adaptogens, it was found that they activate the melatonin signaling pathway by acting through two $G$ protein-coupled membrane receptors MT1 and MT2 and upregulation of the ligand-specific nuclear receptor gene RORA [11] which encodes retinoic acid receptor (RAR)-related orphan nuclear receptor alpha (ROR $\alpha$ ) - a multifunctional transcription activating factor involved in many physiological processes, including regulation of immunity and metabolism, as well as playing an important role in several pathologies, including inflammation, autoimmune diseases, asthma, osteoporosis, cancer, and metabolic syndrome [202,273-275].

Furthermore, the molecular mechanism of actions of melatonin [276,277] and adaptogens are alike in terms of their effects on expression of many genes including UCN, GNRH1, TLR9, GP1BA, PLXNA4, CHRM4, GPR19, VIPR2, RORA, STAT5A, ZFPM2, ZNF396, FLT1, MAPK10, MERTK, PRKCH, and TTN, suggesting that melatonin is an adaptation hormone [278,279], playing an important role in regulation of homeostasis [11]. This conclusion is in line with the common opinion about its physiological role and functions with pleiotropic actions in human, animals, and plants, which include controlling senescence and aging, regulating circadian rhythms, defense response to pathogens and bolstering the immune system $[202,277,280-283]$.

The concentration of melatonin in human serum significantly increases at nighttime from 15-20 to $30-180 \mathrm{pg} / \mathrm{mL}$. However, with age, the level of night melatonin does not increase higher than $30 \mathrm{pg} / \mathrm{mL}$ [284]. The decreased ability to produce melatonin with aging is probably associated with low-grade chronic inflammation and aging-related diseases. Melatonin has been shown to exert anti-inflammatory, antioxidant, and other beneficial actions in aging [202].

Melatonin has been found not only in humans, but also in bacteria, mammals, birds, amphibians, reptiles, fish, and plants. The richest plant sources of melatonin are Coffea spp. with 5800-6500 ng/g [285], Tanacetum parthenium (L.) Sch. Bip. with $2450 \mathrm{ng} / \mathrm{g}$, Viola philipica Cav. with $2368 \mathrm{ng} / \mathrm{g}$, Uncaria rhynchophylla (Miq.) Jacks. with $2460 \mathrm{ng} / \mathrm{g}$, Hypericum perforatum L. with $4390 \mathrm{ng} / \mathrm{g}$, and Morus alba L. with $1510 \mathrm{ng} / \mathrm{g}$, to name just a few $[283,286]$. Some adaptogens also contain melatonin in amounts of $100-500 \mathrm{mg} / \mathrm{g}$, e.g., AP with 511 ng/g, PS with 169 ng/g, SC with 86 ng/g, and GS with 112 ng/g [283,286], and therefore effects of adaptogens on the melatonin signaling pathways may in part be due to its presence. However, other adaptogenic plants, such as RR, ES, and WS, do not contain melatonin, but nonetheless significantly activate the melatonin signaling pathway and upregulate RORA expression [11].

While the content of melatonin in the plants studied ranged from 0.01 to $6500 \mathrm{ng} / \mathrm{g}$ dry weight [283,286-289], assuming a therapeutic daily dose in the range from 1 to $10 \mathrm{~g}$ of dry herbal substance, the consumed melatonin $(<0.065 \mathrm{mg})$ would be significantly lower than its therapeutic daily dose of 3-10 mg. However, these contents are in the range of daily amount ( $30 \mu \mathrm{g}$ ) of melatonin synthesized in adult humans. Since oral bioavailability of melatonin is approximately $3 \%$ in 27 -year-old heathy subjects [290], the consumption of $10 \mathrm{~g}$ of dry herbal substance containing $1000 \mathrm{ng} / \mathrm{g}$ of melatonin can increase its concentration in blood to approximately $12 \mathrm{pg} / \mathrm{mL}$, which is comparable to physiological concentrations of endogenous melatonin in the blood, particularly in elderly people 60-70 years of age, from $15 \mathrm{pg} / \mathrm{mL}$ at daytime to $30 \mathrm{pg} / \mathrm{mL}$ at nighttime [284].

Recently, melatonin was prioritized as a potential SARS-CoV-2 repurposable drug using network pharmacology-based methodologies that quantify the interplay between the virus-host interactome and drug targets in the virus-host protein interactions network $[23,291]$. This conclusion aligns with results of other studies summarized in several reviews [292-294]. For instance, melatonin was found to exhibit therapeutic potential in influenza A H1N1 virus infection, to elicit anti-inflammatory and 
immune modulatory effects-the induction of IL-10 by melatonin occurs via the upregulation of IL-27 in DC - and to exhibit a synergistic effect with an antiviral drug [295]. In another study, intranasally inoculating mice with RSV resulted in oxidative stress changes by increasing $\mathrm{NO}, \mathrm{MDA}$ and -OH levels, and decreasing GSH and SOD activities. Administration of melatonin significantly reversed all these effects. Furthermore, melatonin inhibited the production of proinflammatory cytokines such as $\mathrm{TNF} \alpha$ in serum of RSV-infected mice. These results suggest that melatonin ameliorates RSV-induced lung inflammatory injury in mice via inhibition of oxidative stress and proinflammatory cytokine production and may indeed be considered a novel therapeutic agent in virus-induced pulmonary infection [296]. Melatonin was also found to exert direct viricidal effects against respiratory syncytial virus [296,297], Semliki Forest virus [298] and Venezuelan equine encephalomyelitis virus [299-301].

These effects may be partially associated with melatonin-induced upregulation of RORA encoding ROR $\alpha$ in the liver, thymus, brain, skeletal muscle, skin, lung, adipose tissue, and kidney. ROR $\alpha$ has an anti-inflammatory function in human macrophages. In RORA-deleted cells, a dramatic increase in basal expression of a subset of NF-KB-regulated genes, including TNF, IL-1 $\beta$ and IL-6, at both transcriptional and translational levels was observed [302]. The expression of ROR $\alpha 1$ inhibits TNF $\alpha$-induced IL-6, IL-8 and COX-2 expression in primary smooth-muscle cells [303] and plays an essential role in the development of type 2 innate lymphoid cells (ILC2) and in cytokine production in the ILC3 and Th17 cells $[274,304-306]$. While ROR $\alpha$ is a known inhibitor of NF- KB proinflammatory signaling, it can also be utilized by highly pathogenic influenza H5N1 virus, which can inhibit inflammatory response in monocytes via activation of $\operatorname{ROR} \alpha$ and therefore prevent an effective inflammatory defense response of monocytes [307].

\section{Discussion}

From the data presented here, it can be concluded that adaptogens can play a potentially important role at all stages of viral infection. Adopting a recently proposed phased immunophysiological approach to viral infection [308], adaptogens exerting multitarget effects on the neuroendocrine-immune system by triggering adaptive stress responses have a place in prevention, infection, escalating inflammation and recovery (Figure 2). They provide baseline support through their immunomodulatory, immunostimulatory, and antioxidant effect through all four phases, combat infection through their specific and non-specific antiviral properties, alleviate escalating inflammation through their anti-inflammatory effects, as well as their capacity to repair oxidative stress-induced injuries in compromised cells and tissues, and address secondary disease states and comorbidities through various, infection-related activities.

Another possible benefit of adaptogens in COVID-19 is their effect during convalescence of patients. This is based on the results of an RCT with Chisan/ADAPT-232, a fixed combination of ES with RR and SC in pneumonia [309]. Adjuvant therapy with ADAPT-232 had a positive effect on the recovery of patients by decreasing the duration of the acute phase of the illness, by increasing mental performance of patients in the rehabilitation period, and by improving their quality of life. 


\section{BASELINE HOMEOSTASIS}

Decreased resistance and increased susceptibility to stressors/infections

Sub-optimal function of neuro-endocrine immune system

Low-grade chronic inflammation

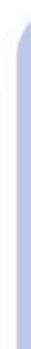

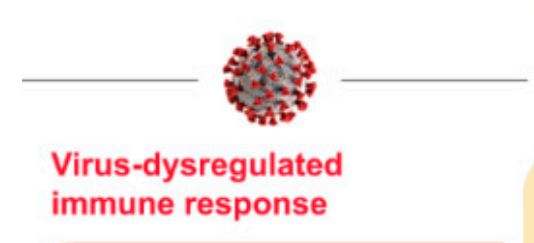

Robust virus replication

Delayed IFN responce

Innate immunity responce:

macrophages, leukocytes

and monocytes infiltration

Suboptimal T-cell and

antibody responces

\section{Escalating inflammation}

Pro-inflammatory cytokines and chemokins expression unregulated: "Cytokine storm"

Severe Oxidative stress: ROS

Enhanced epithelial and endothelial apoptosis

Increased vascular leakage

Impaired virus clearance

\section{Pathogenic inflammation}

Acute lung injury

Acute respiratory distress

syndrome

Death

\section{Prevention:}

Prophylactic

treatment with

Ginseng,

Eleutherococcus,

Rhodiola, Schisandra,

Withania, melatonin

adaptogenic and

stress-protective effect

\section{VIRAL EXPOSURE}

$$
\begin{gathered}
\text { Infection: } \\
\text { Adjuvant therapy } \\
\text { Non-specific antiviral actions } \\
\text { on innate and adaptive } \\
\text { immunity }
\end{gathered}
$$

Inhibition of virus life cycle, RNA synthesis and replication by Ginseng, Rhodiola, Withania, Glycyrrhiza.

\section{Inflammation:}

Adjuvant therapy

Inhibition of inflammatory cytokines expression by

Andrographis, Ginseng, Eleutherococcus, Rhodiola, Schisandra, Withania, Glycyrrhiza

Virus specific antiviral action by Andrographis, Ginseng, Eleutherococcus, Rhodiola, Schisandra, Glycyrrhiza.

\section{Recovery therapy:}

Inhibition of oxidative stress-induced damage

Normalized repair and recovery process

Andrographis, Ginseng, Eleutherococcus, Rhodiola, Schisandra, Withania,

Glycyrrhiza, melatonin.

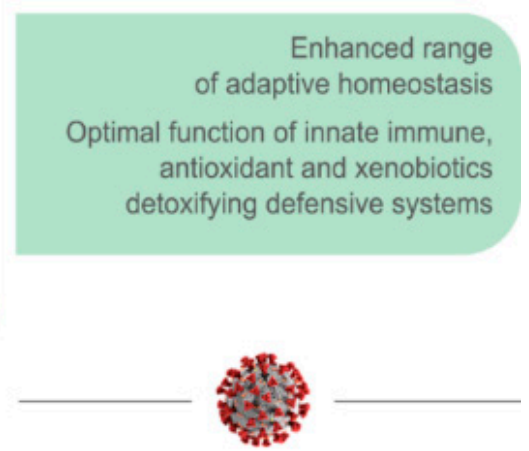

Protective immune response to infection

Non-Robust virus replication Early IFN responce

Innate immunity responce: macrophages, leukocytes and monocytes infiltration

Optimal T-cell and antibody responces

Regulated inflammation

Pro-inflammatory cytokines and chemokins expression regulated

Mild Oxidative stress: ROS

Minimal epithelial and endothelial apaptosis

Reduced vascular leakage

Effective virus clearance

Recovery

Protective immunity Host survival

Figure 2. Schematic diagram of various phases of immune and inflammatory responses to SARS-CoV-2 infection and stages of COVID-19 progression with and without considering potential effects of adaptogenic plants on prevention, infection, inflammation, and recovery phases of viral infection.

\section{Materials and Methods}

Where available, assessment reports published by the European Medicines Agency (EMA)'s Herbal Medicinal Products Committee (HMPC) were consulted to provide the summaries below. 
To cover the time elapsed since publication of these reports and in all other cases, database searches in PubMed, Scopus and Google Scholar were performed. Keywords included scientific and common plant names, in combination with "antiviral", "adaptogen *", "respiratory", "human", and "clinical trial". Relevant primary literature referenced in reviews was retrieved manually. Independent searches were performed regarding relevant information on SARS-CoV-2 and COVID-19, as well as the evidence for therapeutic relevance of phytomedicines in COVID-19.

Author Contributions: Conceptualization, A.P.; methodology, A.P. and T.B.; software, T.B.; validation, A.P. and T.B., writing - original draft preparation, A.P.; writing—review and editing, A.P. and T.B.; visualization, T.B. All authors have read and agreed to the published version of the manuscript.

Funding: This research received no external funding.

Acknowledgments: Authors gratefully acknowledge Patti Rowland for her assistance with creating the figures.

Conflicts of Interest: The authors declare no conflict of interest.

\section{References}

1. Azkur, A.K.; Akdis, M.; Azkur, D.; Sokolowska, M.; van de Veen, W.; Brüggen, M.C.; O’Mahony, L.; Gao, Y.; Nadeau, K.; Akdis, C.A. Immune response to SARS-CoV-2 and mechanisms of immunopathological changes in COVID-19. Allergy 2020, 75, 1564-1581. [CrossRef]

2. Tay, M.Z.; Poh, C.M.; Rénia, L.; MacAry, P.A.; Ng, L.F.P. The trinity of COVID-19: Immunity, inflammation and intervention. Nat. Rev. Immunol. 2020, 20,363-374. [CrossRef] [PubMed]

3. Vardhana, S.A.; Wolchok, J.D. The many faces of the anti-COVID immune response. J. Exp. Med. $2020,217$. [CrossRef] [PubMed]

4. $\quad$ Li, G.; Fan, Y.; Lai, Y.; Han, T.; Li, Z.; Zhou, P.; Pan, P.; Wang, W.; Hu, D.; Liu, X.; et al. Coronavirus infections and immune responses. J. Med. Virol. 2020, 92, 424-432. [CrossRef]

5. Schijns, V.; Lavelle, E.C. Prevention and treatment of COVID-19 disease by controlled modulation of innate immunity. Eur. J. Immunol. 2020, 50, 932-938. [CrossRef]

6. Lega, S.; Naviglio, S.; Volpi, S.; Tommasini, A. Recent Insight into SARS-CoV2 Immunopathology and Rationale for Potential Treatment and Preventive Strategies in COVID-19. Vaccines 2020, 8, 224. [CrossRef]

7. Yang, R.; Liu, H.; Bai, C.; Wang, Y.; Zhang, X.; Guo, R.; Wu, S.; Wang, J.; Leung, E.; Chang, H.; et al. Chemical composition and pharmacological mechanism of Qingfei Paidu Decoction and Ma Xing Shi Gan Decoction against Coronavirus Disease 2019 (COVID-19): In silico and experimental study. Pharmacol. Res. 2020, 157, 104820. [CrossRef]

8. Sakurai, A.; Sasaki, T.; Kato, S.; Hayashi, M.; Tsuzuki, S.-I.; Ishihara, T.; Iwata, M.; Morise, Z.; Doi, Y. Natural History of Asymptomatic SARS-CoV-2 Infection. N. Engl. J. Med. 2020. [CrossRef] [PubMed]

9. Alberts, B.; Johnson, A.; Lewis, J.; Raff, M.; Roberts, K.; Walter, P. Innate immunity. In Molecular Biology of the Cell, 4th ed.; Garland Science: New York, NY, USA, 2002.

10. Efferth, T.; Koch, E. Complex Interactions between Phytochemicals. The Multi-Target Therapeutic Concept of Phytotherapy. Curr. Drug Targets 2011, 12, 122-132. [CrossRef]

11. Panossian, A.; Seo, E.-J.; Efferth, T. Novel molecular mechanisms for the adaptogenic effects of herbal extracts on isolated brain cells using systems biology. Phytomedicine 2018, 50, 257-284. [CrossRef] [PubMed]

12. Panossian, A. Understanding adaptogenic activity: Specificity of the pharmacological action of adaptogens and other phytochemicals. Ann. N. Y. Acad. Sci. 2017, 1401, 49-64. [CrossRef]

13. Lazarev, N.V.; Ljublina, E.I.; Rozin, M.A. State of nonspecific resistance. Patol. Fiziol. Experim. Ter. 1959, 3, $16-21$.

14. Brekhman, I.; Dardymov, I. New substances of plant origin which increase nonspecific resistance. Annu. Rev. Pharmacol. 1969, 9, 419-430. [CrossRef] [PubMed]

15. Wagner, H.; Nörr, H.; Winterhoff, H. Plant adaptogens. Phytomedicine 1994, 1, 63-76. [CrossRef]

16. Yang, Y.M.; Noh, K.; Han, C.Y.; Kim, S.G. Transactivation of Genes Encoding for Phase II Enzymes and Phase III Transporters by Phytochemical Antioxidants. Molecules 2010, 15, 6332-6348. [CrossRef]

17. Pooladanda, V.; Thatikonda, S.; Godugu, C. The current understanding and potential therapeutic options to combat COVID-19. Life Sci. 2020, 254, 117765. [CrossRef] [PubMed] 
18. Khodadadi, E.; Maroufi, P.; Khodadadi, E.; Esposito, I.; Ganbarov, K.; Espsoito, S.; Yousefi, M.; Zeinalzadeh, E.; Kafil, H.S. Study of combining virtual screening and antiviral treatments of the Sars-CoV-2 (Covid-19). Microb. Pathog. 2020, 146, 104241. [CrossRef] [PubMed]

19. Mani, J.S.; Johnson, J.B.; Steel, J.C.; Broszczak, D.A.; Neilsen, P.M.; Walsh, K.B.; Naiker, M. Natural product-derived phytochemicals as potential agents against coronaviruses: A review. Virus Res. 2020, 284, 197989. [CrossRef]

20. Mirza, M.U.; Froeyen, M. Structural elucidation of SARS-CoV-2 vital proteins: Computational methods reveal potential drug candidates against main protease, Nsp12 polymerase and Nsp13 helicase. J. Pharm. Anal. 2020. [CrossRef]

21. Saber-Ayad, M.; Saleh, M.A.; Abu-Gharbieh, E. The Rationale for Potential Pharmacotherapy of COVID-19. Pharmaceuticals 2020, 13, 96. [CrossRef]

22. Wu, C.; Liu, Y.; Yang, Y.; Zhang, P.; Zhong, W.; Wang, Y.; Wang, Q.; Xu, Y.; Li, M.; Li, X.; et al. Analysis of therapeutic targets for SARS-CoV-2 and discovery of potential drugs by computational methods. Acta Pharm. Sin. B 2020, 10, 766-788. [CrossRef] [PubMed]

23. Zhou, H.; Fang, Y.; Xu, T.; Ni, W.-J.; Shen, A.-Z.; Meng, X.-M. Potential therapeutic targets and promising drugs for combating SARS-CoV-2. Br. J. Pharmacol. 2020, 177, 3147-3161. [CrossRef]

24. Kamitani, W.; Narayanan, K.; Huang, C.; Lokugamage, K.; Ikegami, T.; Ito, N.; Kubo, H.; Makino, S. Severe acute respiratory syndrome coronavirus nsp1 protein suppresses host gene expression by promoting host mRNA degradation. Proc. Natl. Acad. Sci. USA 2006, 103, 12885-12890. [CrossRef] [PubMed]

25. Kuba, K.; Imai, Y.; Rao, S.; Gao, H.; Guo, F.; Guan, B.; Huan, Y.; Yang, P.; Zhang, Y.; Deng, W.; et al. A crucial role of angiotensin converting enzyme 2 (ACE2) in SARS coronavirus-induced lung injury. Nat. Med. 2005, 11, 875-879. [CrossRef]

26. Li, W.; Moore, M.J.; Vasilieva, N.; Sui, J.; Wong, S.K.; Berne, M.A.; Somasundaran, M.; Sullivan, J.L.; Luzuriaga, K.; Greenough, T.C.; et al. Angiotensin-converting enzyme 2 is a functional receptor for the SARS coronavirus. Nature 2003, 426, 450-454. [CrossRef] [PubMed]

27. Li, M.-Y.; Li, L.; Zhang, Y.; Wang, X.-S. Expression of the SARS-CoV-2 cell receptor gene ACE2 in a wide variety of human tissues. Infect. Dis Poverty 2020, 9, 1-7. [CrossRef]

28. Hamid, S.; Mir, M.Y.; Rohela, G.K. Novel coronavirus disease (COVID-19): A pandemic (epidemiology, pathogenesis and potential therapeutics). N. Microbes N. Infect. 2020, 35, 100679. [CrossRef]

29. Yi, Y.; Lagniton, P.N.P.; Ye, S.; Li, E.; Xu, R.-H. COVID-19: What has been learned and to be learned about the novel coronavirus disease. Int. J. Biol. Sci. 2020, 16, 1753-1766. [CrossRef]

30. Peron, J.P.S.; Nakaya, H. Susceptibility of the Elderly to SARS-CoV-2 Infection: ACE-2 Overexpression, Shedding, and Antibody-dependent Enhancement (ADE). Clinics 2020, 75. [CrossRef]

31. Cinatl, J.; Morgenstern, B.; Bauer, G.; Chandra, P.; Rabenau, H.; Doerr, H.W. Glycyrrhizin, an active component of liquorice roots, and replication of SARS-associated coronavirus. Lancet 2003, 361, 2045-2046. [CrossRef]

32. Hoever, G.; Baltina, L.; Michaelis, M.; Kondratenko, R.; Baltina, L.; Tolstikov, G.A.; Doerr, H.W.; Cinatl, J. Antiviral Activity of Glycyrrhizic Acid Derivatives against SARS-Coronavirus. J. Med. Chem. 2005, 48, 1256-1259. [CrossRef]

33. Fiore, C.; Eisenhut, M.; Krausse, R.; Ragazzi, E.; Pellati, D.; Armanini, D.; Bielenberg, J. Antiviral effects of Glycyrrhiza species. Phytother. Res. 2008, 22, 141-148. [CrossRef] [PubMed]

34. Cui, Q.; Du, R.; Anantpadma, M.; Schafer, A.; Hou, L.; Tian, J.; Davey, R.A.; Cheng, H.; Rong, L. Identification of Ellagic Acid from Plant Rhodiola rosea L. as an Anti-Ebola Virus Entry Inhibitor. Viruses 2018, 10, 152. [CrossRef]

35. Glatthaar-Saalmüller, B.; Sacher, F.; Esperester, A. Antiviral activity of an extract derived from roots of Eleutherococcus senticosus. Antivir. Res. 2001, 50, 223-228. [CrossRef]

36. Wang, X.-Q.; Li, H.-Y.; Liu, X.-Y.; Zhang, F.-M.; Li, X.; Piao, Y.-A.; Xie, Z.-P.; Chen, Z.-H.; Li, X. The anti-respiratory syncytial virus effect of active compound of Glycyrrhiza GD4 in vitro. Zhong Yao Cai 2006, 29, 692-694. [PubMed]

37. Lee, J.S.; Ko, E.-J.; Hwang, H.S.; Lee, Y.-N.; Kwon, Y.-M.; Kim, M.-C.; Kang, S.-M. Antiviral activity of ginseng extract against respiratory syncytial virus infection. Int. J. Mol. Med. 2014, 34, 183-190. [CrossRef] [PubMed]

38. Ding, Y.; Chen, L.; Wu, W.; Yang, J.; Yang, Z.; Liu, S. Andrographolide inhibits influenza A virus-induced inflammation in a murine model through NF-kB and JAK-STAT signaling pathway. Microbes Infect. 2017, 19, 605-615. [CrossRef] 
39. Yu, B.; Dai, C.Q.; Jiang, Z.Y.; Li, E.Q.; Chen, C.; Wu, X.L.; Chen, J.; Liu, Q.; Zhao, C.L.; He, J.X.; et al. Andrographolide as an anti-H1N1 drug and the mechanism related to retinoic acid-inducible gene-I-like receptors signaling pathway. Chin. J. Integr. Med. 2014, 20, 540-545. [CrossRef]

40. Ko, H.-C.; Wei, B.-L.; Chiou, W.-F. The effect of medicinal plants used in Chinese folk medicine on RANTES secretion by virus-infected human epithelial cells. J. Ethnopharmacol. 2006, 107, 205-210. [CrossRef]

41. Fedorov, Y.V.; Vasilyeva, O.A.; Vasilyev, N.V. Effect of some stimulants of plant origin on the development of antibodies and immunomorphological reactions during acarid-borne encephalitis. Cent. Nerv. Syst. Stimul. 1966, 1, 99-105.

42. Protasova, S.F.; Zykov, M.P. Antiviral effect of Eleutherococcus in experimental influenza infection. In New Data on Eleutherococcus, Proceedings of the II International Symposium on Eleutherococcus, Moscow, USSR, 1984; Far East Academy of Sciences of the USSR: Vladivostok, USSR, 1986; pp. 123-126.

43. Yan, W.; Chen, J.; Wei, Z.; Wang, X.; Zeng, Z.; Tembo, D.; Wang, Y.; Wang, X. Effect of eleutheroside B1 on non-coding RNAs and protein profiles of influenza A virus-infected A549 cells. Int. J. Mol. Med. 2020, 45, 753-768. [CrossRef] [PubMed]

44. Yan, W.; Zheng, C.; He, J.; Zhang, W.; Huang, X.A.; Li, X.; Wang, Y.; Wang, X. Eleutheroside B1 mediates its anti-influenza activity through POLR2A and N-glycosylation. Int. J. Mol. Med. 2018, 42, 2776-2792. [CrossRef] [PubMed]

45. Wolkerstorfer, A.; Kurz, H.; Bachhofner, N.; Szolar, O.H.J. Glycyrrhizin inhibits influenza A virus uptake into the cell. Antivir. Res. 2009, 83, 171-178. [CrossRef] [PubMed]

46. Choi, J.-G.; Jin, Y.-H.; Lee, H.; Oh, T.W.; Yim, N.-H.; Cho, W.-K.; Ma, J.Y. Protective Effect of Panax notoginseng Root Water Extract against Influenza A Virus Infection by Enhancing Antiviral Interferon-Mediated Immune Responses and Natural Killer Cell Activity. Front. Immunol. 2017, 8, 1542. [CrossRef]

47. Dong, W.; Farooqui, A.; Leon, A.J.; Kelvin, D.J. Inhibition of influenza A virus infection by ginsenosides. PLoS ONE 2017, 12, e0171936. [CrossRef]

48. Kim, E.-H.; Kim, S.-W.; Park, S.-J.; Kim, S.; Yu, K.-M.; Kim, S.G.; Lee, S.H.; Seo, Y.-K.; Cho, N.-H.; Kang, K.; et al. Greater Efficacy of Black Ginseng (CJ EnerG) over Red Ginseng against Lethal Influenza A Virus Infection. Nutrients 2019, 11, 1879. [CrossRef]

49. Lee, J.S.; Hwang, H.S.; Ko, E.-J.; Lee, Y.-N.; Kwon, Y.-M.; Kim, M.-C.; Kang, S.-M. Immunomodulatory Activity of Red Ginseng against Influenza A Virus Infection. Nutrients 2014, 6, 517-529. [CrossRef]

50. Wang, Y.; Jung, Y.-J.; Kim, K.-H.; Kwon, Y.; Kim, Y.-J.; Zhang, Z.; Kang, H.-S.; Wang, B.-Z.; Quan, F.-S.; Kang, S.-M. Antiviral Activity of Fermented Ginseng Extracts against a Broad Range of Influenza Viruses. Viruses 2018, 10, 471. [CrossRef]

51. Xu, M.L.; Kim, H.J.; Choi, Y.R.; Kim, H.-J. Intake of Korean red ginseng extract and saponin enhances the protection conferred by vaccination with inactivated influenza a virus. J. Ginseng Res. 2012, 36, 396-402. [CrossRef]

52. Yin, S.Y.; Kim, H.J.; Kim, H.-J. A Comparative Study of the Effects of Whole Red Ginseng Extract and Polysaccharide and Saponin Fractions on Influenza A (H1N1) Virus Infection. Biol. Pharm. Bull. 2013, 36, 1002-1007. [CrossRef]

53. Yoo, D.G.; Kim, M.C.; Park, M.K.; Song, J.M.; Quan, F.S.; Park, K.M.; Cho, Y.K.; Kang, S.M. Protective Effect of Korean Red Ginseng Extract on the Infections by H1N1 and H3N2 Influenza Viruses in Mice. J. Med. Food 2012, 15, 855-862. [CrossRef] [PubMed]

54. Jeong, H.J.; Ryu, Y.B.; Park, S.-J.; Kim, J.H.; Kwon, H.-J.; Kim, J.H.; Park, K.H.; Rho, M.-C.; Lee, W.S. Neuraminidase inhibitory activities of flavonols isolated from Rhodiola rosea roots and their in vitro anti-influenza viral activities. Bioorganic Med. Chem. 2009, 17, 6816-6823. [CrossRef] [PubMed]

55. Utsunomiya, T.; Kobayashi, M.; Pollard, R.B.; Suzuki, F. Glycyrrhizin, an active component of licorice roots, reduces morbidity and mortality of mice infected with lethal doses of influenza virus. Antimicrob. Agents Chemother. 1997, 41, 551. [CrossRef]

56. Park, E.H.; Yum, J.; Ku, K.B.; Kim, H.M.; Kang, Y.M.; Kim, J.C.; Kim, J.A.; Kang, Y.K.; Seo, S.H. Red Ginseng-containing diet helps to protect mice and ferrets from the lethal infection by highly pathogenic H5N1 influenza virus. J. Ginseng Res. 2014, 38, 40-46. [CrossRef] [PubMed]

57. Sornpet, B.; Potha, T.; Tragoolpua, Y.; Pringproa, K. Antiviral activity of five Asian medicinal pant crude extracts against highly pathogenic H5N1 avian influenza virus. Asian Pac. J. Trop. Med. 2017, 10, 871-876. [CrossRef] [PubMed] 
58. Michaelis, M.; Geiler, J.; Naczk, P.; Sithisarn, P.; Ogbomo, H.; Altenbrandt, B.; Leutz, A.; Doerr, H.W.; Cinatl, J. Glycyrrhizin inhibits highly pathogenic H5N1 influenza A virus-induced pro-inflammatory cytokine and chemokine expression in human macrophages. Med. Microbiol. Immunol. 2010, 199, 291-297. [CrossRef]

59. Panraksa, P.; Ramphan, S.; Khongwichit, S.; Smith, D.R. Activity of andrographolide against dengue virus. Antivir. Res. 2017, 139, 69-78. [CrossRef]

60. Ramalingam, S.; Karupannan, S.; Padmanaban, P.; Vijayan, S.; Sheriff, K.; Palani, G.; Krishnasamy, K.K. Anti-dengue activity of Andrographis paniculata extracts and quantification of dengue viral inhibition by SYBR green reverse transcription polymerase chain reaction. AYU 2018, 39, 87-91. [CrossRef]

61. Wintachai, P.; Kaur, P.; Lee, R.C.H.; Ramphan, S.; Kuadkitkan, A.; Wikan, N.; Ubol, S.; Roytrakul, S.; Chu, J.J.H.; Smith, D.R. Activity of andrographolide against chikungunya virus infection. Sci. Rep. 2015, 5, 14179. [CrossRef]

62. Diwaker, D.; Mishra, K.P.; Ganju, L.; Singh, S.B. Rhodiola inhibits dengue virus multiplication by inducing innate immune response genes RIG-I, MDA5 and ISG in human monocytes. Arch. Virol. 2014, 159, 1975-1986. [CrossRef]

63. Wang, H.; Ding, Y.; Zhou, J.; Sun, X.; Wang, S. The in vitro and in vivo antiviral effects of salidroside from Rhodiola rosea L. against coxsackievirus B3. Phytomedicine 2009, 16, 146-155. [CrossRef]

64. Jain, J.; Narayanan, V.; Chaturvedi, S.; Pai, S.; Sunil, S. In Vivo Evaluation of Withania somnifera-Based Indian Traditional Formulation (Amukkara Choornam), Against Chikungunya Virus-Induced Morbidity and Arthralgia. J. Evid. Based Integr. Med. 2018, 23. [CrossRef] [PubMed]

65. Enmozhi, S.K.; Raja, K.; Sebastine, I.; Joseph, J. Andrographolide as a potential inhibitor of SARS-CoV-2 main protease: An in silico approach. J. Biomol. Struct. Dyn. 2020, 1-7. [CrossRef] [PubMed]

66. Zhang, D.-H.; Wu, K.-L.; Zhang, X.; Deng, S.-Q.; Peng, B. In silico screening of Chinese herbal medicines with the potential to directly inhibit 2019 novel coronavirus. J. Integr. Med. 2020, 18, 152-158. [CrossRef] [PubMed]

67. Murck, H. Symptomatic Protective Action of Glycyrrhizin (Licorice) in COVID-19 Infection? Front. Immunol. 2020, 11, 1239. [CrossRef] [PubMed]

68. Shao, Z.-J.; Zheng, X.-W.; Feng, T.; Huang, J.; Chen, J.; Wu, Y.-Y.; Zhou, L.-M.; Tu, W.-W.; Li, H. Andrographolide exerted its antimicrobial effects by upregulation of human $\beta$-defensin-2 induced through p38 MAPK and NF-kB pathway in human lung epithelial cells. Can. J. Physiol. Pharmacol. 2012, 90, 647-653. [CrossRef]

69. Xiong, W.-B.; Shao, Z.-J.; Xiong, Y.; Chen, J.; Sun, Y.; Zhu, L.; Zhou, L.-M. Dehydroandrographolide enhances innate immunity of intestinal tract through up-regulation the expression of hBD-2. Daru J. Pharm. Sci. 2015, 23, 37. [CrossRef]

70. Gao, H.; Wang, J. Andrographolide inhibits multiple myeloma cells by inhibiting the TLR4/NF- $\mathrm{kB}$ signaling pathway. Mol. Med. Rep. 2016, 13, 1827-1832. [CrossRef]

71. Kim, A.-Y.; Shim, H.-J.; Shin, H.-M.; Lee, Y.J.; Nam, H.; Kim, S.Y.; Youn, H.-S. Andrographolide suppresses TRIF-dependent signaling of toll-like receptors by targeting TBK1. Int. Immunopharmacol. 2018, 57, 172-180. [CrossRef]

72. Han, S.B.; Yoon, Y.D.; Ahn, H.J.; Lee, H.S.; Lee, C.W.; Yoon, W.K.; Park, S.K.; Kim, H.M. Toll-like receptor-mediated activation of $\mathrm{B}$ cells and macrophages by polysaccharide isolated from cell culture of Acanthopanax senticosus. Int. Immunopharmacol. 2003, 3, 1301-1312. [CrossRef]

73. Lee, S.; Lee, H.H.; Shin, Y.S.; Kang, H.; Cho, H. The anti-HSV-1 effect of quercetin is dependent on the suppression of TLR-3 in Raw 264.7 cells. Arch. Pharmacal Res. 2017, 40, 623-630. [CrossRef]

74. Lee, S.A.; Lee, S.H.; Kim, J.Y.; Lee, W.S. Effects of glycyrrhizin on lipopolysaccharide-induced acute lung injury in a mouse model. J. Thorac. Dis. 2019, 11, 1287-1302. [CrossRef]

75. Peng, L.N.; Li, L.; Qiu, Y.F.; Miao, J.H.; Gao, X.Q.; Zhou, Y.; Shi, Z.X.; Xu, Y.L.; Shao, D.H.; Wei, J.C.; et al. Glycyrrhetinic acid extracted from Glycyrrhiza uralensis Fisch. induces the expression of Toll-like receptor 4 in Ana-1 murine macrophages. J. Asian Nat. Prod. Res. 2011, 13, 942-950. [CrossRef]

76. Schröfelbauer, B.; Raffetseder, J.; Hauner, M.; Wolkerstorfer, A.; Ernst, W.; Szolar Oliver, H.J. Glycyrrhizin, the main active compound in liquorice, attenuates pro-inflammatory responses by interfering with membrane-dependent receptor signalling. Biochem. J. 2009, 421, 473-482. [CrossRef] 
77. Wang, Q.; Shen, J.; Yan, Z.; Xiang, X.; Mu, R.; Zhu, P.; Yao, Y.; Zhu, F.; Chen, K.; Chi, S.; et al. Dietary Glycyrrhiza uralensis extracts supplementation elevated growth performance, immune responses and disease resistance against Flavobacterium columnare in yellow catfish (Pelteobagrus fulvidraco). Fish. Shellfish Immunol. 2020, 97, 153-164. [CrossRef]

78. Ahn, H.; Han, B.-C.; Kim, J.; Kang, S.G.; Kim, P.-H.; Jang, K.H.; So, S.H.; Lee, S.-H.; Lee, G.-S. Nonsaponin fraction of Korean Red Ginseng attenuates cytokine production via inhibition of TLR4 expression. J. Ginseng Res. 2019, 43, 291-299. [CrossRef]

79. Ahn, J.Y.; Choi, I.S.; Shim, J.Y.; Yun, E.K.; Yun, Y.S.; Jeong, G.; Song, J.Y. The immunomodulator ginsan induces resistance to experimental sepsis by inhibiting Toll-like receptor-mediated inflammatory signals. Eur. J. Immunol. 2006, 36, 37-45. [CrossRef]

80. Kim, T.-W.; Joh, E.-H.; Kim, B.; Kim, D.-H. Ginsenoside Rg5 ameliorates lung inflammation in mice by inhibiting the binding of LPS to toll-like receptor-4 on macrophages. Int. Immunopharmacol. 2012, 12, 110-116. [CrossRef]

81. Nakaya, T.A.; Kita, M.; Kuriyama, H.; Iwakura, Y.; Imanishi, J. Panax ginseng Induces Production of Proinflammatory Cytokines via Toll-like Receptor. J. Interferon Cytokine Res. 2004, 24, 93-100. [CrossRef]

82. Nguyen, C.T.; Luong, T.T.; Lee, S.Y.; Kim, G.L.; Kwon, H.; Lee, H.-G.; Park, C.-K.; Rhee, D.-K. Panax ginseng aqueous extract prevents pneumococcal sepsis in vivo by potentiating cell survival and diminishing inflammation. Phytomedicine 2015, 22, 1055-1061. [CrossRef]

83. Paik, S.; Choe, J.H.; Choi, G.-E.; Kim, J.-E.; Kim, J.-M.; Song, G.Y.; Jo, E.-K. Rg6, a rare ginsenoside, inhibits systemic inflammation through the induction of interleukin-10 and microRNA-146a. Sci. Rep. 2019, 9, 4342. [CrossRef] [PubMed]

84. Mishra, K.P.; Ganju, L.; Chanda, S.; Karan, D.; Sawhney, R.C. Aqueous extract of Rhodiola imbricata rhizome stimulates Toll-like receptor 4, granzyme-B and Th1 cytokines in vitro. Immunobiology 2009, 214, 27-31. [CrossRef] [PubMed]

85. Mishra, K.P.; Ganju, L.; Singh, S.B. Anti-cellular and immunomodulatory potential of aqueous extract of Rhodiola imbricata rhizome. Immunopharmacol. Immunotoxicol. 2012, 34, 513-518. [CrossRef]

86. Shan, Y.; Jiang, B.; Yu, J.; Wang, J.; Wang, X.; Li, H.; Wang, C.; Chen, J.; Sun, J. Protective Effect of Schisandra chinensis Polysaccharides Against the Immunological Liver Injury in Mice Based on Nrf2/ARE and TLR4/NF-kB Signaling Pathway. J. Med. Food 2019, 22, 885-895. [CrossRef]

87. Sun, K.; Huang, R.; Yan, L.; Li, D.-T.; Liu, Y.-Y.; Wei, X.-H.; Cui, Y.-C.; Pan, C.-S.; Fan, J.-Y.; Wang, X.; et al. Schisandrin Attenuates Lipopolysaccharide-Induced Lung Injury by Regulating TLR-4 and Akt/FoxO1 Signaling Pathways. Front. Physiol. 2018, 9, 1104. [CrossRef]

88. Zhao, T.; Feng, Y.; Li, J.; Mao, R.; Zou, Y.; Feng, W.; Zheng, D.; Wang, W.; Chen, Y.; Yang, L.; et al. Schisandra polysaccharide evokes immunomodulatory activity through TLR 4-mediated activation of macrophages. Int. J. Biol. Macromol. 2014, 65, 33-40. [CrossRef]

89. Maitra, R.; Porter, M.A.; Huang, S.; Gilmour, B.P. Inhibition of NFkB by the natural product Withaferin A in cellular models of Cystic Fibrosis inflammation. J. Inflamm. 2009, 6, 15. [CrossRef]

90. Kang, J.-W.; Koh, E.-J.; Lee, S.-M. Melatonin protects liver against ischemia and reperfusion injury through inhibition of toll-like receptor signaling pathway. J. Pineal Res. 2011, 50, 403-411. [CrossRef]

91. Kim, S.W.; Kim, S.; Son, M.; Cheon, J.H.; Park, Y.S. Melatonin controls microbiota in colitis by goblet cell differentiation and antimicrobial peptide production through Toll-like receptor 4 signalling. Sci. Rep. 2020, 10, 2232. [CrossRef]

92. Kowalewska, M.; Herman, A.P.; Szczepkowska, A.; Skipor, J. The effect of melatonin from slow-release implants on basic and TLR-4-mediated gene expression of inflammatory cytokines and their receptors in the choroid plexus in ewes. Res. Vet. Sci. 2017, 113, 50-55. [CrossRef]

93. Lucas, K.; Maes, M. Role of the Toll Like Receptor (TLR) Radical Cycle in Chronic Inflammation: Possible Treatments Targeting the TLR4 Pathway. Mol. Neurobiol. 2013, 48, 190-204. [CrossRef] [PubMed]

94. Xu, X.; Wang, G.; Ai, L.; Shi, J.; Zhang, J.; Chen, Y.-X. Melatonin suppresses TLR9-triggered proinflammatory cytokine production in macrophages by inhibiting ERK1/2 and AKT activation. Sci. Rep. 2018, 8, 15579. [CrossRef] [PubMed] 
95. Panossian, A.; Davtyan, T.; Gukassyan, N.; Gukasova, G.; Mamikonyan, G.; Gabrielian, E.; Wikman, G. Effect of Andrographolide and Kan Jang-Fixed combination of extract SHA-10 and extract SHE-3-On proliferation of human lymphocytes, production of cytokines and immune activation markers in the whole blood cells culture. Phytomedicine 2002, 9, 598-605. [CrossRef] [PubMed]

96. Zykov, M.P.; Protasova, S.F. Prospects of immunostimulating vaccination against influenza including the use of Eleutherococcus and other preparations of plant origin. In New Data on Eleutherococcus, Proceedings of the 2nd International Symposium on Eleutherococcus, Moscow, 1984; Far East Academy of Sciences of the USSR: Vladivostok, USSR, 1986; pp. 118-122.

97. Bohn, B.; Nebe, C.T.; Birr, C. Flow-cytometric studies with eleutherococcus senticosus extract as an immunomodulatory agent. Arzneim. Forsch. 1987, 37, 1193-1196.

98. Bohn, B.; Nebe, C.T.; Birr, C. Immunopharmacological effects of eleutherococcus senticosus extract as determined by quantitative flow cytometry. Int. J. Immunopharmacol. 1988, 10, 67. [CrossRef]

99. Kupin, V.I.; Polevaya, E.S.; Sorokin, A.M. Increased immunologic reactivity of lymphocytes in oncologic patients treated with Eleutherococcus extract. In New Data on Eleutherococcus, Proceedings of the 2nd International Symposium on Eleutherococcus, Moscow, 1984; Far East Academy of Sciences of the USSR: Vladivostok, USSR, 1986; pp. 216-220.

100. Wacker, A. Über die Interferon induzierende und immunstimulierende Wirkung von Eleutherococcus. Erfahrungsheilkunde 1983, 32, 339-343.

101. Wacker, A.; Eichler, A.; Lodemann, E. The molecular mechanism of virus inhibition by Eleutherococcus. In New Data on Eleutherococcus, Proceedings of the 2nd International Symposium on Eleutherococcus, Moscow, 1984; Far East Academy of Sciences of the USSR: Vladivostok, USSR, 1986; pp. 13-15.

102. Wacker, A.; Eilmes, H.G. Virushemmung mit Eleutherokokk Fluid-Extrakt. Erfahrungsheilkunde 1978, 27, 346-351.

103. Kour, K.; Pandey, A.; Suri, K.A.; Satti, N.K.; Gupta, K.K.; Bani, S. Restoration of stress-induced altered T cell function and corresponding cytokines patterns by Withanolide A. Int. Immunopharmacol. 2009, 9, 1137-1144. [CrossRef]

104. Malik, F.; Singh, J.; Khajuria, A.; Suri, K.A.; Satti, N.K.; Singh, S.; Kaul, M.K.; Kumar, A.; Bhatia, A.; Qazi, G.N. A standardized root extract of Withania somnifera and its major constituent withanolide-A elicit humoral and cell-mediated immune responses by up regulation of Th1-dominant polarization in BALB/c mice. Life Sci. 2007, 80, 1525-1538. [CrossRef]

105. Khan, B.; Ahmad, S.F.; Bani, S.; Kaul, A.; Suri, K.A.; Satti, N.K.; Athar, M.; Qazi, G.N. Augmentation and proliferation of $\mathrm{T}$ lymphocytes and Th-1 cytokines by Withania somnifera in stressed mice. Int. Immunopharmacol. 2006, 6, 1394-1403. [CrossRef]

106. Khan, S.; Malik, F.; Suri, K.A.; Singh, J. Molecular insight into the immune up-regulatory properties of the leaf extract of Ashwagandha and identification of Th1 immunostimulatory chemical entity. Vaccine 2009, 27, 6080-6087. [CrossRef] [PubMed]

107. Chao, W.-W.; Kuo, Y.-H.; Hsieh, S.-L.; Lin, B.-F. Inhibitory effects of ethyl acetate extract of Andrographis paniculata on NF-kB trans-activation activity and LPS-induced acute inflammation in mice. Evid. Based Complementary Altern. Med. 2011, 2011, 254531. [CrossRef] [PubMed]

108. Panossian, A.; Hambartsumyan, M.; Panosyan, L.; Abrahamyan, H.; Mamikonyan, G.; Gabrielyan, E.; Amaryan, G.; Astvatsatryan, V.; Wikman, G. Plasma nitric oxide level in familial Mediterranean fever and its modulations by Immuno-Guard. Nitric Oxide 2003, 9, 103-110. [CrossRef] [PubMed]

109. Jin, L.; Schmiech, M.; El Gaafary, M.; Zhang, X.; Syrovets, T.; Simmet, T. A comparative study on root and bark extracts of Eleutherococcus senticosus and their effects on human macrophages. Phytomedicine 2020, 68, 153181. [CrossRef] [PubMed]

110. Panossian, A.G. Adaptogens: Tonic Herbs for Fatigue and Stress. Altern. Complementary Ther. 2003, 9, 327-331. [CrossRef]

111. Chen, S.; Li, X.; Wang, Y.; Mu, P.; Chen, C.; Huang, P.; Liu, D. Ginsenoside Rb1 attenuates intestinal ischemia/reperfusion-induced inflammation and oxidative stress via activation of the PI3K/Akt/Nrf2 signaling pathway. Mol. Med. Rep. 2019, 19, 3633-3641. [CrossRef]

112. Iqbal, H.; Rhee, D.-K. Ginseng alleviates microbial infections of the respiratory tract: A review. J. Ginseng Res. 2020, 44, 194-204. [CrossRef] 
113. Zhou, F.; Wang, M.; Ju, J.; Wang, Y.; Liu, Z.; Zhao, X.; Yan, Y.; Yan, S.; Luo, X.; Fang, Y. Schizandrin A protects against cerebral ischemia-reperfusion injury by suppressing inflammation and oxidative stress and regulating the AMPK/Nrf2 pathway regulation. Am. J. Transl. Res. 2019, 11, 199-209.

114. Vanden Berghe, W.; Sabbe, L.; Kaileh, M.; Haegeman, G.; Heyninck, K. Molecular insight in the multifunctional activities of Withaferin, A. Biochem. Pharmacol. 2012, 84, 1282-1291. [CrossRef]

115. Sánchez-López, A.L.; Ortiz, G.G.; Pacheco-Moises, F.P.; Mireles-Ramírez, M.A.; Bitzer-Quintero, O.K.; Delgado-Lara, D.L.C.; Ramírez-Jirano, L.J.; Velázquez-Brizuela, I.E. Efficacy of Melatonin on Serum Pro-inflammatory Cytokines and Oxidative Stress Markers in Relapsing Remitting Multiple Sclerosis. Arch. Med. Res. 2018, 49, 391-398. [CrossRef]

116. Schmolz, M.W.; Sacher, F.; Aicher, B. The synthesis of Rantes, G-CSF, IL-4, IL-5, IL-6, IL-12 and IL-13 in human whole-blood cultures is modulated by an extract from Eleutherococcus senticosus L. roots. Phytother. Res. 2001, 15, 268-270. [CrossRef] [PubMed]

117. Maurya, S.P.; Das, B.K.; Singh, R.; Tyagi, S. Effect of Withania somnifer on CD38 expression on CD8+ T lymphocytes among patients of HIV infection. Clin. Immunol. 2019, 203, 122-124. [CrossRef] [PubMed]

118. Kishore, V.; Yarla, N.S.; Zameer, F.; Nagendra Prasad, M.N.; Santosh, M.S.; More, S.S.; Rao, D.G.; Dhananjaya, B.L. Inhibition of Group IIA Secretory Phospholipase A2 and its Inflammatory Reactions in Mice by Ethanolic Extract of Andrographis paniculata, a Well-known Medicinal Food. Pharmacogn. Res. 2016, 8, 213-216. [CrossRef]

119. Li, Y.; Zhao, H.; Wang, Y.; Zheng, H.; Yu, W.; Chai, H.; Zhang, J.; Falck, J.R.; Guo, A.M.; Yue, J.; et al. Isoliquiritigenin induces growth inhibition and apoptosis through downregulating arachidonic acid metabolic network and the deactivation of PI3K/Akt in human breast cancer. Toxicol. Appl. Pharmacol. 2013, 272, 37-48. [CrossRef]

120. Wang, Y.; Wang, S.; Bao, Y.; Li, T.; Chang, X.; Yang, G.; Meng, X. Multipathway Integrated Adjustment Mechanism of Glycyrrhiza Triterpenes Curing Gastric Ulcer in Rats. Pharm. Mag. 2017, 13, $209-215$. [CrossRef]

121. Xie, C.; Li, X.; Wu, J.; Liang, Z.; Deng, F.; Xie, W.; Zhu, M.; Zhu, J.; Zhu, W.; Geng, S.; et al. Anti-inflammatory Activity of Magnesium Isoglycyrrhizinate Through Inhibition of Phospholipase A2/Arachidonic Acid Pathway. Inflammation 2015, 38, 1639-1648. [CrossRef]

122. Cha, T.W.; Kim, M.; Kim, M.; Chae, J.S.; Lee, J.H. Blood pressure-lowering effect of Korean red ginseng associated with decreased circulating Lp-PLA 2 activity and lysophosphatidylcholines and increased dihydrobiopterin level in prehypertensive subjects. Hypertens. Res. 2016, 39, 449-456. [CrossRef]

123. Irfan, M.; Kim, M.; Rhee, M.H. Anti-platelet role of Korean ginseng and ginsenosides in cardiovascular diseases. J. Ginseng Res. 2020, 44, 24-32. [CrossRef]

124. Kim, D.Y.; Ro, J.Y.; Lee, C.H. 20(S)-Protopanaxatriol inhibits release of inflammatory mediators in immunoglobulin E-mediated mast cell activation. J. Ginseng Res. 2015, 39, 189-198. [CrossRef]

125. Shin, J.-H.; Kwon, H.-W.; Rhee, M.H.; Park, H.-J. Inhibitory effects of thromboxane A2 generation by ginsenoside Ro due to attenuation of cytosolic phospholipase A2 phosphorylation and arachidonic acid release. J. Ginseng Res. 2019, 43, 236-241. [CrossRef]

126. Bawa, A.S.; Khanum, F. Anti-inflammatory activity of Rhodiola rosea-“A second-generation adaptogen”. Phytother. Res. 2009, 23, 1099-1102. [CrossRef] [PubMed]

127. Ohkura, Y.; Mizoguchi, Y.; Morisawa, S.; Takeda, S.; Aburada, M.; Hosoya, E. Effect of Gomisin A (TJN-101) on the Arachidonic Acid Cascade in Macrophages. Jpn. J. Pharmacol. 1990, 52, 331-336. [CrossRef]

128. Lizano, S.; Domont, G.; Perales, J. Natural phospholipase A2 myotoxin inhibitor proteins from snakes, mammals and plants. Toxicon 2003, 42, 963-977. [CrossRef] [PubMed]

129. Machiah, D.K.; Gowda, T.V. Purification of a post-synaptic neurotoxic phospholipase A2 from Naja naja venom and its inhibition by a glycoprotein from Withania somnifera. Biochimie 2006, 88, 701-710. [CrossRef]

130. Madhusudan, M.; Zameer, F.; Naidu, A.; Dhananjaya, B.L.; Hegdekatte, R. Evaluating the inhibitory potential of Withania somnifera on platelet aggregation and inflammation enzymes: An in vitro and in silico study. Pharm. Biol. 2016, 54, 1936-1941. [CrossRef]

131. Chao, W.-W.; Kuo, Y.-H.; Li, W.-C.; Lin, B.-F. The production of nitric oxide and prostaglandin E2 in peritoneal macrophages is inhibited by Andrographis paniculata, Angelica sinensis and Morus alba ethyl acetate fractions. J. Ethnopharmacol. 2009, 122, 68-75. [CrossRef] 
132. Panossian, A.; Seo, E.-J.; Efferth, T. Effects of anti-inflammatory and adaptogenic herbal extracts on gene expression of eicosanoids signaling pathways in isolated brain cells. Phytomedicine 2019,60, 152881. [CrossRef] [PubMed]

133. Amroyan, E.; Gabrielian, E.; Panossian, A.; Wikman, G.; Wagner, H. Inhibitory effect of andrographolide from Andrographis paniculata on PAF-induced platelet aggregation. Phytomedicine 1999, 6, 27-31. [CrossRef]

134. Burgos, R.A.; Hidalgo, M.A.; Monsalve, J.; LaBranche, T.P.; Eyre, P.; Hancke, J.L. 14-deoxyandrographolide as a platelet activating factor antagonist in bovine neutrophils. Planta Med. 2005, 71, 604-608. [CrossRef] [PubMed]

135. Jung, K.Y.; Kim, D.S.; Oh, S.R.; Lee, I.S.; Lee, J.J.; Park, J.D.; Kim, S.I.; Lee, H.-K. Platelet Activating Factor Antagonist Activity of Ginsenosides. Biol. Pharm. Bull. 1998, 21, 79-80. [CrossRef]

136. Teng, C.-M.; Kuo, S.-C.; Ko, F.-N.; Lee, J.-C.; Lee, L.-G.; Chen, S.-C.; Huang, T.-F. Antiplatelet actions of panaxynol and ginsenosides isolated from ginseng. Biochim. Biophys. Acta Gen. Subj. 1989, 990, 315-320. [CrossRef]

137. Jung, K.Y.; Lee, I.S.; Oh, S.R.; Kim, D.S.; Lee, H.K. Lignans with platelet activating factor antagonist activity from Schisandra chinensis (Turcz.) Baill. Phytomedicine 1997, 4, 229-231. [CrossRef]

138. Lee, I.S.; Jung, K.Y.; Oh, S.R.; Park, S.H.; Ahn, K.S.; Lee, H.-K. Structure-Activity Relationships of Lignans from Schisandra chinensis as Platelet Activating Factor Antagonists. Biol. Pharm. Bull. 1999, 22, $265-267$. [CrossRef]

139. Chiou, W.-F.; Chen, C.-F.; Lin, J.-J. Mechanisms of suppression of inducible nitric oxide synthase (iNOS) expression in RAW 264.7 cells by andrographolide. Br. J. Pharmacol. 2000, 129, 1553-1560. [CrossRef]

140. Panossian, A.; Hambardzumyan, M.; Hovhanissyan, A.; Wikman, G. The Adaptogens Rhodiola and Schizandra Modify the Response to Immobilization Stress in Rabbits by Suppressing the Increase of Phosphorylated Stress-activated Protein Kinase, Nitric Oxide and Cortisol. Drug Target. Insights 2007, 2. [CrossRef]

141. Dai, Y.; Chen, S.-R.; Chai, L.; Zhao, J.; Wang, Y.; Wang, Y. Overview of pharmacological activities of Andrographis paniculata and its major compound andrographolide. Crit. Rev. Food Sci. Nutr. 2019, 59, S17-S29. [CrossRef]

142. Fei, X.J.; Zhu, L.L.; Xia, L.M.; Peng, W.B.; Wang, Q. Acanthopanax senticosus attenuates inflammation in lipopolysaccharide-induced acute lung injury by inhibiting the NF-кB pathway. Genet. Mol. Res. 2014, 13, 10537-10544. [CrossRef]

143. Han, J.; Liu, L.; Yu, N.; Chen, J.; Liu, B.; Yang, D.; Shen, G. Polysaccharides from Acanthopanax senticosus enhances intestinal integrity through inhibiting TLR4/NF- $\mathrm{B}$ signaling pathways in lipopolysaccharide-challenged mice. Anim. Sci. J. 2016, 87, 1011-1018. [CrossRef]

144. Kim, J.-A.; Kim, D.-K.; Jin, T.; Kang, O.-H.; Choi, Y.-A.; Choi, S.-C.; Kim, T.-H.; Nah, Y.-H.; Choi, S.-J.; Kim, Y.-H.; et al. Acanthoic acid inhibits IL-8 production via MAPKs and NF- $\kappa B$ in a TNF- $\alpha$-stimulated human intestinal epithelial cell line. Clin. Chim. Acta 2004, 342, 193-202. [CrossRef]

145. Lin, Q.-Y.; Jin, L.-J.; Cao, Z.-H.; Li, H.-Q.; Xu, Y.-P. Protective effect of Acanthopanax senticosus extract against endotoxic shock in mice. J. Ethnopharmacol. 2008, 118, 495-502. [CrossRef]

146. Lin, Q.-Y.; Jin, L.-J.; Cao, Z.-H.; Xu, Y.-P. Inhibition of inducible nitric oxide synthase by Acanthopanax senticosus extract in RAW264.7 macrophages. J. Ethnopharmacol. 2008, 118, 231-236. [CrossRef] [PubMed]

147. Kim, H.S.; Park, S.Y.; Kim, E.K.; Ryu, E.Y.; Kim, Y.H.; Park, G.; Lee, S.J. Acanthopanax senticosus has a heme oxygenase-1 signaling-dependent effect on Porphyromonas gingivalis lipopolysaccharide-stimulated macrophages. J. Ethnopharmacol. 2012, 142, 819-828. [CrossRef] [PubMed]

148. Wang, X.; Zhuang, X.; Wei, R.; Wang, C.; Xue, X.; Mao, L. Protective effects of Acanthopanax vs. Ulinastatin against severe acute pancreatitis-induced brain injury in rats. Int. Immunopharmacol. 2015, 24, 285-298. [CrossRef] [PubMed]

149. Yamazaki, T.; Shimosaka, S.; Sasaki, H.; Matsumura, T.; Tukiyama, T.; Tokiwa, T. (+)-Syringaresinol-di -O- $\beta$-d-glucoside, a phenolic compound from Acanthopanax senticosus Harms, suppresses proinflammatory mediators in SW982 human synovial sarcoma cells by inhibiting activating protein-1 and/or nuclear factor- $\mathrm{kB}$ activities. Toxicol. Vitr. 2007, 21, 1530-1537. [CrossRef] [PubMed]

150. Zhang, A.; Liu, Z.; Sheng, L.; Wu, H. Protective effects of syringin against lipopolysaccharide-induced acute lung injury in mice. J. Surg. Res. 2017, 209, 252-257. [CrossRef] 
151. Kang, B.; Kim, C.Y.; Hwang, J.; Sun, S.; Yang, H.; Suh, H.J.; Choi, H.-S. Red ginseng extract regulates differentiation of monocytes to macrophage and inflammatory signalings in human monocytes. Food Sci. Biotechnol. 2019, 28, 1819-1828. [CrossRef]

152. Oh, G.S.; Pae, H.O.; Choi, B.M.; Seo, E.A.; Kim, D.H.; Shin, M.K.; Kim, J.D.; Kim, J.B.; Chung, H.T. 20(S)-Protopanaxatriol, one of ginsenoside metabolites, inhibits inducible nitric oxide synthase and cyclooxygenase-2 expressions through inactivation of nuclear factor- $\mathrm{kB}$ in RAW 264.7 macrophages stimulated with lipopolysaccharide. Cancer Lett. 2004, 205, 23-29. [CrossRef]

153. Surh, Y.-J.; Lee, J.-Y.; Choi, K.-J.; Ko, S.-R. Effects of Selected Ginsenosides on Phorbol Ester-Induced Expression of Cyclooxygenase-2 and Activation of NF-kB and ERK1/2 in Mouse Skin. Ann. N. Y. Acad. Sci. 2002, 973, 396-401. [CrossRef]

154. Surh, Y.J.; Na, H.K.; Lee, J.Y.; Keum, Y.S. Molecular mechanisms underlying anti-tumor promoting activities of heat-processed Panax ginseng C.A. Meyer. J. Korean Med. Sci 2001, 16, S38-S41. [CrossRef]

155. Keum, Y.-S.; Han, S.S.; Chun, K.-S.; Park, K.-K.; Park, J.-H.; Lee, S.K.; Surh, Y.-J. Inhibitory effects of the ginsenoside Rg3 on phorbol ester-induced cyclooxygenase-2 expression, NF- $\kappa$ B activation and tumor promotion. Mutat. Res. Fundam. Mol. Mech. Mutagenesis 2003, 523-524, 75-85. [CrossRef]

156. Borgonetti, V.; Governa, P.; Biagi, M.; Dalia, P.; Corsi, L. Rhodiola rosea L. modulates inflammatory processes in a CRH-activated BV2 cell model. Phytomedicine 2020,68, 153143. [CrossRef]

157. Hu, R.; Wang, M.-Q.; Ni, S.-H.; Wang, M.; Liu, L.-Y.; You, H.-Y.; Wu, X.-H.; Wang, Y.-J.; Lu, L.; Wei, L.-B. Salidroside ameliorates endothelial inflammation and oxidative stress by regulating the AMPK/NF-kB/NLRP3 signaling pathway in AGEs-induced HUVECs. Eur. J. Pharmacol. 2020, 867, 172797. [CrossRef] [PubMed]

158. Li, J.-S.; Fan, L.-Y.; Yuan, M.-D.; Xing, M.-Y. Salidroside Inhibits Lipopolysaccharide-ethanol-induced Activation of Proinflammatory Macrophages via Notch Signaling Pathway. Curr. Med. Sci. 2019, 39, 526-533. [CrossRef] [PubMed]

159. Tang, H.; Gao, L.; Mao, J.; He, H.; Liu, J.; Cai, X.; Lin, H.; Wu, T. Salidroside protects against bleomycin-induced pulmonary fibrosis: Activation of Nrf2-antioxidant signaling, and inhibition of NF-kB and TGF- $\beta 1 / \mathrm{Smad}-2 /-3$ pathways. Cell Stress Chaperones 2016, 21, 239-249. [CrossRef] [PubMed]

160. Xin, X.; Yao, D.; Zhang, K.; Han, S.; Liu, D.; Wang, H.; Liu, X.; Li, G.; Huang, J.; Wang, J. Protective effects of Rosavin on bleomycin-induced pulmonary fibrosis via suppressing fibrotic and inflammatory signaling pathways in mice. Biomed. Pharmacother. 2019, 115, 108870. [CrossRef]

161. Xu, F.; Xu, J.; Xiong, X.; Deng, Y. Salidroside inhibits MAPK, NF-kB, and STAT3 pathways in psoriasis-associated oxidative stress via SIRT1 activation. Redox Rep. 2019, 24, 70-74. [CrossRef]

162. Zhang, P.; Li, Y.; Guo, R.; Zang, W. Salidroside Protects Against Advanced Glycation End Products-Induced Vascular Endothelial Dysfunction. Med. Sci. Monit. 2018, 24, 2420-2428. [CrossRef] [PubMed]

163. Zhang, X.; Lai, W.; Ying, X.; Xu, L.; Chu, K.; Brown, J.; Chen, L.; Hong, G. Salidroside Reduces Inflammation and Brain Injury After Permanent Middle Cerebral Artery Occlusion in Rats by Regulating PI3K/PKB/Nrf2/NFkB Signaling Rather than Complement C3 Activity. Inflammation 2019, 42, 1830-1842. [CrossRef]

164. Ci, X.; Ren, R.; Xu, K.; Li, H.; Yu, Q.; Song, Y.; Wang, D.; Li, R.; Deng, X. Schisantherin A Exhibits Anti-inflammatory Properties by Down-Regulating NF- $\mathrm{B}$ and MAPK Signaling Pathways in Lipopolysaccharide-Treated RAW 264.7 Cells. Inflammation 2010, 33, 126-136. [CrossRef]

165. Kwon, D.H.; Cha, H.-J.; Choi, E.O.; Leem, S.-H.; Kim, G.-Y.; Moon, S.-K.; Chang, Y.-C.; Yun, S.-J.; Hwang, H.J.; Kim, B.W.; et al. Schisandrin A suppresses lipopolysaccharide-induced inflammation and oxidative stress in RAW 264.7 macrophages by suppressing the NF- $\mathrm{kB}$, MAPKs and PI3K/Akt pathways and activating Nrf2/HO-1 signaling. Int. J. Mol. Med. 2018, 41, 264-274. [CrossRef]

166. Luo, G.; Cheng, B.C.-Y.; Zhao, H.; Fu, X.-Q.; Xie, R.; Zhang, S.-F.; Pan, S.-Y.; Zhang, Y. Schisandra Chinensis Lignans Suppresses the Production of Inflammatory Mediators Regulated by NF-kB, AP-1, and IRF3 in Lipopolysaccharide-Stimulated RAW264.7 Cells. Molecules 2018, 23, 3319. [CrossRef] [PubMed]

167. Ran, J.; Ma, C.; Xu, K.; Xu, L.; He, Y.; Moqbel, S.A.A.; Hu, P.; Jiang, L.; Chen, W.; Bao, J.; et al. Schisandrin $\mathrm{B}$ ameliorated chondrocytes inflammation and osteoarthritis via suppression of NF- $\mathrm{B}$ and MAPK signal pathways. Drug Des. Devel. Ther. 2018, 12, 1195-1204. [CrossRef] [PubMed]

168. Song, F.-J.; Zeng, K.-W.; Chen, J.-F.; Li, Y.; Song, X.-M.; Tu, P.-F.; Wang, X.-M. Extract of Fructus Schisandrae chinensis Inhibits Neuroinflammation Mediator Production from Microglia via NF-K B and MAPK Pathways. Chin. J. Integr. Med. 2019, 25, 131-138. [CrossRef] 
169. Heyninck, K.; Lahtela-Kakkonen, M.; Van der Veken, P.; Haegeman, G.; Vanden Berghe, W. Withaferin A inhibits NF-kappaB activation by targeting cysteine 179 in IKK $\beta$. Biochem. Pharmacol. 2014, 91, 501-509. [CrossRef]

170. Mulabagal, V.; Subbaraju, G.V.; Rao, C.V.; Sivaramakrishna, C.; DeWitt, D.L.; Holmes, D.; Sung, B.; Aggarwal, B.B.; Tsay, H.-S.; Nair, M.G. Withanolide sulfoxide from Aswagandha roots inhibits nuclear transcription factor-kappa-B, cyclooxygenase and tumor cell proliferation. Phytother. Res. 2009, 23, 987-992. [CrossRef] [PubMed]

171. Oh, J.H.; Kwon, T.K. Withaferin A inhibits tumor necrosis factor- $\alpha$-induced expression of cell adhesion molecules by inactivation of Akt and NF- $\mathrm{kB}$ in human pulmonary epithelial cells. Int. Immunopharmacol. 2009, 9, 614-619. [CrossRef] [PubMed]

172. Singh, D.; Aggarwal, A.; Maurya, R.; Naik, S. Withania somnifera inhibits NF-kB and AP-1 transcription factors in human peripheral blood and synovial fluid mononuclear cells. Phytother. Res. 2007, 21, 905-913. [CrossRef]

173. Moniruzzaman, M.; Ghosal, I.; Das, D.; Chakraborty, S.B. Melatonin ameliorates $\mathrm{H}_{2} \mathrm{O}_{2}$-induced oxidative stress through modulation of Erk/Akt/NFkB pathway. Biol. Res. 2018, 51. [CrossRef]

174. Adeoye, B.O.; Asenuga, E.R.; Oyagbemi, A.A.; Omobowale, T.O.; Adedapo, A.A. The Protective Effect of the Ethanol Leaf Extract of Andrographis Paniculata on Cisplatin-Induced Acute Kidney Injury in Rats Through nrf2/KIM-1 Signalling Pathway. Drug Res. 2018, 68, 23-32. [CrossRef]

175. Lee, J.-C.; Tseng, C.-K.; Young, K.-C.; Sun, H.-Y.; Wang, S.-W.; Chen, W.-C.; Lin, C.-K.; Wu, Y.-H. Andrographolide exerts anti-hepatitis $C$ virus activity by up-regulating haeme oxygenase- 1 via the p38 MAPK/Nrf2 pathway in human hepatoma cells. Br. J. Pharmacol. 2014, 171, 237-252. [CrossRef]

176. Lin, H.-C.; Su, S.-L.; Lu, C.-Y.; Lin, A.-H.; Lin, W.-C.; Liu, C.-S.; Yang, Y.-C.; Wang, H.-M.; Lii, C.-K.; Chen, H.-W. Andrographolide inhibits hypoxia-induced HIF-1 $\alpha$-driven endothelin 1 secretion by activating Nrf2/HO-1 and promoting the expression of prolyl hydroxylases 2/3 in human endothelial cells. Environ. Toxicol. 2017, 32, 918-930. [CrossRef]

177. Lu, C.-Y.; Yang, Y.-C.; Li, C.-C.; Liu, K.-L.; Lii, C.-K.; Chen, H.-W. Andrographolide inhibits TNF $\alpha$-induced ICAM-1 expression via suppression of NADPH oxidase activation and induction of HO-1 and GCLM expression through the PI3K/Akt/Nrf2 and PI3K/Akt/AP-1 pathways in human endothelial cells. Biochem. Pharmacol. 2014, 91, 40-50. [CrossRef] [PubMed]

178. Mussard, E.; Cesaro, A.; Lespessailles, E.; Legrain, B.; Berteina-Raboin, S.; Toumi, H. Andrographolide, a Natural Antioxidant: An Update. Antioxidants 2019, 8, 571. [CrossRef] [PubMed]

179. Pan, C.-W.; Yang, S.-X.; Pan, Z.-Z.; Zheng, B.; Wang, J.-Z.; Lu, G.-R.; Xue, Z.-X.; Xu, C.-L. Andrographolide ameliorates d-galactosamine/lipopolysaccharide-induced acute liver injury by activating Nrf2 signaling pathway. Oncotarget 2017, 8, 41202-41210. [CrossRef] [PubMed]

180. Seo, J.Y.; Pyo, E.; An, J.-P.; Kim, J.; Sung, S.H.; Oh, W.K. Andrographolide Activates Keap1/Nrf2/ARE/HO-1 Pathway in HT22 Cells and Suppresses Microglial Activation by A $\beta_{42}$ through Nrf2-Related Inflammatory Response. Mediat. Inflamm. 2017, 2017, 5906189. [CrossRef] [PubMed]

181. Tan, W.S.D.; Liao, W.; Zhou, S.; Wong, W.S.F. Is there a future for andrographolide to be an anti-inflammatory drug? Deciphering its major mechanisms of action. Biochem. Pharmacol. 2017, 139, 71-81. [CrossRef]

182. Wong, S.Y.; Tan, M.G.K.; Wong, P.T.H.; Herr, D.R.; Lai, M.K.P. Andrographolide induces Nrf2 and heme oxygenase 1 in astrocytes by activating p38 MAPK and ERK. J. Neuroinflammation 2016, 13, 251. [CrossRef]

183. Wang, X.; Hai, C.X.; Liang, X.; Yu, S.X.; Zhang, W.; Li, Y.L. The protective effects of Acanthopanax senticosus Harms aqueous extracts against oxidative stress: Role of Nrf2 and antioxidant enzymes. J. Ethnopharmacol. 2010, 127, 424-432. [CrossRef]

184. Chu, S.F.; Zhang, Z.; Zhou, X.; He, W.B.; Chen, C.; Luo, P.; Liu, D.D.; Ai, Q.D.; Gong, H.F.; Wang, Z.Z.; et al. Ginsenoside Rg1 protects against ischemic/reperfusion-induced neuronal injury through miR-144/Nrf2/ARE pathway. Acta Pharmacol. Sin. 2019, 40, 13-25. [CrossRef]

185. Li, J.-P.; Gao, Y.; Chu, S.-F.; Zhang, Z.; Xia, C.-Y.; Mou, Z.; Song, X.-Y.; He, W.-B.; Guo, X.-F.; Chen, N.-H. $\mathrm{Nrf} 2$ pathway activation contributes to anti-fibrosis effects of ginsenoside $\mathrm{Rg} 1$ in a rat model of alcohol- and CCl4-induced hepatic fibrosis. Acta Pharmacol. Sin. 2014, 35, 1031-1044. [CrossRef]

186. Saw, C.L.L.; Yang, A.Y.; Cheng, D.C.; Boyanapalli, S.S.S.; Su, Z.-Y.; Khor, T.O.; Gao, S.; Wang, J.; Jiang, Z.-H.; Kong, A.-N.T. Pharmacodynamics of Ginsenosides: Antioxidant Activities, Activation of Nrf2, and Potential Synergistic Effects of Combinations. Chem. Res. Toxicol. 2012, 25, 1574-1580. [CrossRef] [PubMed] 
187. Shaukat, A.; Yang, C.; Yang, Y.; Guo, Y.-F.; Jiang, K.; Guo, S.; Liu, J.; Zhang, T.; Zhao, G.; Ma, X.; et al. Ginsenoside $\mathrm{Rb} 1$ : A novel therapeutic agent in Staphylococcus aureus-induced Acute Lung Injury with special reference to Oxidative stress and Apoptosis. Microb. Pathog. 2020, 143, 104109. [CrossRef] [PubMed]

188. Han, J.; Xiao, Q.; Lin, Y.-H.; Zheng, Z.-Z.; He, Z.-D.; Hu, J.; Chen, L.-D. Neuroprotective effects of salidroside on focal cerebral ischemia/reperfusion injury involve the nuclear erythroid 2-related factor 2 pathway. Neural Regen Res. 2015, 10, 1989-1996. [CrossRef] [PubMed]

189. Li, R.; Wang, S.; Li, T.; Wu, L.; Fang, Y.; Feng, Y.; Zhang, L.; Chen, J.; Wang, X. Salidroside Protects Dopaminergic Neurons by Preserving Complex I Activity via DJ-1/Nrf2-Mediated Antioxidant Pathway. Parkinsons Dis. 2019, 2019, 6073496. [CrossRef] [PubMed]

190. Zhu, Y.; Zhang, Y.-J.; Liu, W.-W.; Shi, A.-W.; Gu, N. Salidroside Suppresses HUVECs Cell Injury Induced by Oxidative Stress through Activating the Nrf2 Signaling Pathway. Molecules 2016, 21, 1033. [CrossRef]

191. Gao, J.; Yu, Z.; Jing, S.; Jiang, W.; Liu, C.; Yu, C.; Sun, J.; Wang, C.; Chen, J.; Li, H. Protective effect of Anwulignan against D-galactose-induced hepatic injury through activating p38 MAPK-Nrf2-HO-1 pathway in mice. Clin. Interv. Aging 2018, 13, 1859-1869. [CrossRef]

192. Shen, Z.; Geng, Q.; Huang, H.; Yao, H.; Du, T.; Chen, L.; Wu, Z.; Miao, X.; Shi, P. Antioxidative and Cardioprotective Effects of Schisandra chinensis Bee Pollen Extract on Isoprenaline-Induced Myocardial Infarction in Rats. Molecules 2019, 24, 1090. [CrossRef]

193. Zhang, X.; Jing, S.; Lin, H.; Sun, W.; Jiang, W.; Yu, C.; Sun, J.; Wang, C.; Chen, J.; Li, H. Anti-fatigue effect of anwulignan via the NRF2 and PGC-1 $\alpha$ signaling pathway in mice. Food Funct. 2019, 10, 7755-7766. [CrossRef]

194. Heyninck, K.; Sabbe, L.; Chirumamilla, C.S.; Szarc vel Szic, K.; Vander Veken, P.; Lemmens, K.J.A.; Lahtela-Kakkonen, M.; Naulaerts, S.; Op de Beeck, K.; Laukens, K.; et al. Withaferin A induces heme oxygenase (HO-1) expression in endothelial cells via activation of the Keap1/Nrf2 pathway. Biochem. Pharmacol. 2016, 109, 48-61. [CrossRef]

195. Palliyaguru, D.L.; Chartoumpekis, D.V.; Wakabayashi, N.; Skoko, J.J.; Yagishita, Y.; Singh, S.V.; Kensler, T.W. Withaferin A induces Nrf2-dependent protection against liver injury: Role of Keap1-independent mechanisms. Free Radic. Biol. Med. 2016, 101, 116-128. [CrossRef]

196. Reuland, D.J.; Khademi, S.; Castle, C.J.; Irwin, D.C.; McCord, J.M.; Miller, B.F.; Hamilton, K.L. Upregulation of phase II enzymes through phytochemical activation of Nrf2 protects cardiomyocytes against oxidant stress. Free Radic. Biol. Med. 2013, 56, 102-111. [CrossRef] [PubMed]

197. Shin, E.-J.; Chung, Y.H.; Le, H.-L.T.; Jeong, J.H.; Dang, D.-K.; Nam, Y.; Wie, M.B.; Nah, S.-Y.; Nabeshima, Y.-I.; Nabeshima, T.; et al. Melatonin Attenuates Memory Impairment Induced by Klotho Gene Deficiency Via Interactive Signaling Between MT2 Receptor, ERK, and Nrf2-Related Antioxidant Potential. Int. J. Neuropsychopharmacol. 2015, 18. [CrossRef] [PubMed]

198. Carota, G.; Raffaele, M.; Sorrenti, V.; Salerno, L.; Pittalà, V.; Intagliata, S. Ginseng and heme oxygenase-1: The link between an old herb and a new protective system. Fitoterapia 2019, 139, 104370. [CrossRef] [PubMed]

199. Asea, A.; Kaur, P.; Panossian, A.; Wikman, K.G. Evaluation of molecular chaperons Hsp72 and neuropeptide $\mathrm{Y}$ as characteristic markers of adaptogenic activity of plant extracts. Phytomedicine 2013, 20, 1323-1329. [CrossRef]

200. Panossian, A.; Wikman, G.; Kaur, P.; Asea, A. Adaptogens exert a stress-protective effect by modulation of expression of molecular chaperones. Phytomedicine 2009, 16, 617-622. [CrossRef]

201. Panossian, A.; Wikman, G.; Kaur, P.; Asea, A. Adaptogens Stimulate Neuropeptide Y and Hsp72 Expression and Release in Neuroglia Cells. Front. Neurosci. 2012, 6, 6. [CrossRef]

202. Carrillo-Vico, A.; Lardone, P.J.; Álvarez-Sánchez, N.; Rodríguez-Rodríguez, A.; Guerrero, J.M. Melatonin: Buffering the immune system. Int. J. Mol. Sci. 2013, 14, 8638-8683. [CrossRef]

203. He, B.; Zhao, Y.; Xu, L.; Gao, L.; Su, Y.; Lin, N.; Pu, J. The nuclear melatonin receptor ROR $\alpha$ is a novel endogenous defender against myocardial ischemia/reperfusion injury. J. Pineal Res. 2016, 60, 313-326. [CrossRef]

204. Thakur, A.; Dey, A.; Chatterjee, S.; Kumar, V. Reverse Ayurvedic Pharmacology of Ashwagandha as an Adaptogenic Anti-Diabetic Plant: A Pilot Study. Curr. Tradit. Med. 2015, 1, 51-61. [CrossRef]

205. Thakur, A.K.; Chatterjee, S.S.; Kumar, V. Adaptogenic potential of andrographolide: An active principle of the king of bitters (Andrographis paniculata). J. Tradit. Complementary Med. 2015, 5, 42-50. [CrossRef] 
206. Kaur, P.; Makanjuola, V.O.; Arora, R.; Singh, B.; Arora, S. Immunopotentiating significance of conventionally used plant adaptogens as modulators in biochemical and molecular signalling pathways in cell mediated processes. Biomed. Pharmacother. 2017, 95, 1815-1829. [CrossRef]

207. EMA. Final Assessment Report on Glycyrrhiza Glabra L. and/or Glycyrrhiza Inflata Bat. and/or Glycyrrhiza Uralensis Fisch., Radix; Committee on Herbal Medicinal Products (HMPC). European Medicines Agency: Amsterdam, The Netherlands, 2013.

208. EMA. Final Assessment Report on Panax Ginseng C.A. Meyer, Radix; Committee on Herbal Medicinal Products (HMPC). European Medicines Agency: Amsterdam, The Netherlands, 2014.

209. EMA. Final Assessment Report on Rhodiola Rosea; Committee on Herbal Medicinal Products (HMPC). European Medicines Agency: Amsterdam, The Netherlands, 2012.

210. Hancke, J.L.; Burgos, R.A.; Ahumada, F. Schisandra chinensis (Turcz.) Baill. Fitoterapia 1999, 70, 451-471. [CrossRef]

211. Nowak, A.; Zakłos-Szyda, M.; Błasiak, J.; Nowak, A.; Zhang, Z.; Zhang, B. Potential of Schisandra chinensis (Turcz.) Baill. in Human Health and Nutrition: A Review of Current Knowledge and Therapeutic Perspectives. Nutrients 2019, 11, 333. [CrossRef] [PubMed]

212. Panossian, A.; Wikman, G. Pharmacology of Schisandra chinensis Bail.: An overview of Russian research and uses in medicine. J. Ethnopharmacol. 2008, 118, 183-212. [CrossRef]

213. Szopa, A. Current knowledge of Schisandra chinensis (Turcz.) Baill. (Chinese magnolia vine) as a medicinal plant species: A review on the bioactive components, pharmacological properties, analytical and biotechnological studies. Phytochem. Rev. 2017, 16, 195-218. [CrossRef] [PubMed]

214. Dar, N.J.; Hamid, A.; Ahmad, M. Pharmacologic overview of Withania somnifera, the Indian Ginseng. Cell. Mol. Life Sci. 2015, 72, 4445-4460. [CrossRef]

215. Kalra, R.; Kaushik, N. Withania somnifera (Linn.) Dunal: A review of chemical and pharmacological diversity. Phytochem. Rev. 2017, 16, 953-987. [CrossRef]

216. Tripathi, N.; Shrivastava, D.; Ahmad Mir, B.; Kumar, S.; Govil, S.; Vahedi, M.; Bisen, P.S. Metabolomic and biotechnological approaches to determine therapeutic potential of Withania somnifera (L.) Dunal: A review. Phytomedicine 2018, 50, 127-136. [CrossRef]

217. Reyes, B.A.S.; Bautista, N.D.; Tanquilut, N.C.; Anunciado, R.V.; Leung, A.B.; Sanchez, G.C.; Magtoto, R.L.; Castronuevo, P.; Tsukamura, H.; Maeda, K.I. Anti-diabetic potentials of Momordica charantia and Andrographis paniculata and their effects on estrous cyclicity of alloxan-induced diabetic rats. J. Ethnopharmacol. 2006, 105, 196-200. [CrossRef]

218. Subramanian, R.; Asmawi, M.Z. Inhibition of $\alpha$-Glucosidase by Andrographis paniculata. Ethanol Extract in Rats. Pharm. Biol. 2006, 44, 600-606. [CrossRef]

219. Zhang, X.; Tan, B.K.-H. Anti-diabetic property of ethanolic extract of Andrographis paniculata in streptozotocin-diabetic rats. Acta Pharmacol. Sin. 2000, 21, 1157-1164. [PubMed]

220. Zhang, X.F.; Tan, B.K.H. Antihyperglycaemic and anti-oxidant properties of andrographis paniculata in normal and diabetic rats. Clin. Exp. Pharmacol. Physiol. 2000, 27, 358-363. [CrossRef] [PubMed]

221. EMA. Final Assessment Report on Eleutherococcus Senticosus (Rupr. et Maxim.) Maxim., Radix; Committee on Herbal Medicinal Products (HMPC). European Medicines Agency: Amsterdam, The Netherlands, 2014.

222. Akowuah, G.; Zhari, I.; Mariam, A.; Yam, M. Absorption of andrographolides from Andrographis paniculata and its effect on CCl4-induced oxidative stress in rats. Food Chem. Toxicol. 2009, 47, 2321-2326. [CrossRef] [PubMed]

223. Lin, F.L.; Wu, S.J.; Lee, S.C.; Ng, L.T. Antioxidant, antioedema and analgesic activities of Andrographis paniculata extracts and their active constituent andrographolide. Phytother. Res. 2009, 23, 958-964. [CrossRef]

224. Verma, N.; Vinayak, M. Antioxidant action of Andrographis paniculata on lymphoma. Mol. Biol. Rep. 2008, 35, 535-540. [CrossRef]

225. Sheeja, K.; Kuttan, G. Protective Effect of Andrographis paniculata and Andrographolide on Cyclophosphamide-Induced Urothelial Toxicity. Integr. Cancer Ther. 2006, 5, 244-251. [CrossRef]

226. Saranya, P.; Geetha, A.; Selvamathy, S.N. A biochemical study on the gastroprotective effect of andrographolide in rats induced with gastric ulcer. Indian J. Pharm. Sci. 2011, 73, 550. [CrossRef]

227. Wasman, S.Q.; Mahmood, A.A.; Chua, L.S.; Alshawsh, M.A.; Hamdan, S. Antioxidant and gastroprotective activities of Andrographis paniculata (Hempedu Bumi) in Sprague Dawley rats. Indian J. Exp. Biol. 2011, 49, 767-772. 
228. Chander, R.; Srivastava, V.; Tandon And, J.S.; Kapoor, N.K. Antihepatotoxic Activity of Diterpenes of Andrographis Paniculata (Kal-Megh) Against Plasmodium Berghei-Induced Hepatic Damage in Mastomys Natalensis. Int. J. Pharmacogn. 1995, 33, 135-138. [CrossRef]

229. Koh, P.H.; Mokhtar, R.A.M.; Iqbal, M. Andrographis paniculata ameliorates carbon tetrachloride (CCl4)-dependent hepatic damage and toxicity: Diminution of oxidative stress. Redox Rep. 2011, 16, 134-143. [CrossRef]

230. Nagalekshmi, R.; Menon, A.; Chandrasekharan, D.K.; Nair, C.K.K. Hepatoprotective activity of Andrographis Paniculata and Swertia Chirayita. Food Chem. Toxicol. 2011, 49, 3367-3373. [CrossRef] [PubMed]

231. Pramyothin, P.; Udomuksorn, W.; Poungshompoo, S.; Chaichantipyuth, C. Hepatoprotective effect of Andrographis paniculata and its constituent, andrographolide, on ethanol hepatotoxicity in rats. Asia Pac. J. Pharmacol. 1994, 9, 73-78.

232. Wang, D.; Zhao, H. Prevention of atherosclerotic arterial stenosis and restenosis after angioplasty with Andrographis paniculata nees and fish oil. Experimental studies of effects and mechanisms. Chin. Med. J. 1994, 107, 464-470. [PubMed]

233. Zhang, C.Y.; Tan, B.K.H. Mechanisms of cardiovascular activity of Andrographis paniculata in the anaesthetized rat. J. Ethnopharmacol. 1997, 56, 97-101. [CrossRef]

234. Sheeja, K.; Guruvayoorappan, C.; Kuttan, G. Antiangiogenic activity of Andrographis paniculata extract and andrographolide. Int. Immunopharmacol. 2007, 7, 211-221. [CrossRef] [PubMed]

235. Sheeja, K.; Kuttan, G. Modulation of Natural Killer Cell Activity, Antibody-Dependent Cellular Cytotoxicity, and Antibody-Dependent Complement-Mediated Cytotoxicity by Andrographolide in Normal and Ehrlich Ascites Carcinoma-Bearing Mice. Integr. Cancer Ther. 2007, 6, 66-73. [CrossRef]

236. Sheeja, K.; Kuttan, G. Activation of Cytotoxic T Lymphocyte Responses and Attenuation of Tumor Growth in vivo by Andrographis paniculata Extract and Andrographolide. Immunopharmacol. Immunotoxicol. 2007, 29, 81-93. [CrossRef]

237. Mandal, S.C.; Dhara, A.K.; Maiti, B.C. Studies on psychopharmacological activity ofAndrographis paniculata extract. Phytother. Res. 2001, 15, 253-256. [CrossRef]

238. Thakur, A.K.; Soni, U.K.; Rai, G.; Chatterjee, S.S.; Kumar, V. Protective Effects of Andrographis paniculata Extract and Pure Andrographolide Against Chronic Stress-Triggered Pathologies in Rats. Cell. Mol. Neurobiol. 2014, 34, 1111-1121. [CrossRef]

239. Zhang, J.-J.; Gao, T.-T.; Wang, Y.; Wang, J.-L.; Guan, W.; Wang, Y.-J.; Wang, C.-N.; Liu, J.-F.; Jiang, B. Andrographolide Exerts Significant Antidepressant-Like Effects Involving the Hippocampal BDNF System in Mice. Int. J. Neuropsychopharmacol. 2019, 22, 585-600. [CrossRef]

240. Amsterdam, J.D.; Panossian, A.G. Rhodiola rosea L. as a putative botanical antidepressant. Phytomedicine 2016, 23, 770-783. [CrossRef] [PubMed]

241. Darbinyan, V.; Aslanyan, G.; Amroyan, E.; Gabrielyan, E.; Malmström, C.; Panossian, A. Clinical trial of Rhodiola rosea L. extract SHR-5 in the treatment of mild to moderate depression. Nord. J. Psychiatry 2007, 61, 343-348. [CrossRef] [PubMed]

242. Hu, X.-Y.; Wu, R.-H.; Logue, M.; Blondel, C.; Lai, L.Y.W.; Stuart, B.; Flower, A.; Fei, Y.-T.; Moore, M.; Shepherd, J.; et al. Andrographis paniculata (Chuān Xīn Lián) for symptomatic relief of acute respiratory tract infections in adults and children: A systematic review and meta-analysis. PLOS ONE 2017, 12, e0181780. [CrossRef] [PubMed]

243. Hancke, J.; Burgos, R.; Caceres, D.; Wikman, G. A double-blind study with a new monodrug Kan Jang: Decrease of symptoms and improvement in the recovery from common colds. Phytother. Res. 1995, 9, 559-562. [CrossRef]

244. Caceres, D.; Hancke, J.; Burgos, R.; Sandberg, F.; Wikman, G. Use of visual analogue scale measurements (VAS) to asses the effectiveness of standardized Andrographis paniculata extract SHA-10 in reducing the symptoms of common cold. A randomized double blind-placebo study. Phytomedicine 1999, 6, 217-223. [CrossRef]

245. Melchior, J.; Palm, S.; Wikman, G. Controlled clinical study of standardized Andrographis paniculata extract in common cold-A pilot trial. Phytomedicine 1997, 3, 315-318. [CrossRef]

246. Saxena, R.C.; Singh, R.; Kumar, P.; Yadav, S.C.; Negi, M.P.S.; Saxena, V.S.; Joshua, A.J.; Vijayabalaji, V.; Goudar, K.S.; Venkateshwarlu, K.; et al. A randomized double blind placebo controlled clinical evaluation of extract of Andrographis paniculata (KalmCold $\left.{ }^{\mathrm{TM}}\right)$ in patients with uncomplicated upper respiratory tract infection. Phytomedicine 2010, 17, 178-185. [CrossRef] [PubMed] 
247. Gagarin, I.A. Eleutherococcus in the Prophylaxis of the disease incidence in the Arctic. In Adaptation and Adaptogens, Proceedings of the 2nd Symposium, May 1975; Academy of Science of the USSR Far East Science Centre: Vladivostok, USSR, 1977; p. 128.

248. Galanova, L.K. Eleutherococcus in preventive maintenance of a flu and relapses of hypertonic illness. In Adaptation and Adaptogens, Proceedings of the 2nd Symposium; Academy of Science of the USSR Far East Science Centre: Vladivostok, USSR, 1977; pp. 126-127.

249. Schezin, A.K.; Zinkovich, V.I.; Matsuk, V.S. Tentative data on the mass Eleutherococcus prophylaxis of influenza at the main assembly line and metallurgic plant of the Volga Automobile Plant. Proceedings of 2nd All-Union Conference on Human Adaptation to Different Conditions, Novosibirsk, USSR; 1977; pp. 44-46.

250. Shadrin, A.S.; Kustikova, Y.G.; Belogolovkina, N.A. Estimation of prophylactic and immunostimulating effects of Eleutherococcus and Schizandra chinensis preparations. In New Data on Eleutherococcus Proceedings of the II International Symposium on Eleutherococcus, Moscow, USSR, 1984; Far East Academy of Sciences of the USSR: Vladivostok, USSR, 1986; pp. 213-215.

251. Barkan, A.; Gaŭduchenia, L.; Makarenko, I. Effect of Eleutherococcus on respiratory viral infectious morbidity in children in organized collectives. Pediatria 1980, 65-66.

252. Sheparev, A.A.Z.; Kozlenko, I.Y. Effect of preventive administration of Eleutherococcus extract on health of children under school age. In New Data on Eleutherococcus Proceedings of the II International Symposium on Eleutherococcus, Moscow, USSR, 1984; Far East Academy of Sciences of the USSR: Vladivostok, USSR, 1986; pp. 201-203.

253. Kwon, Y.J.; Son, D.H.; Chung, T.H.; Lee, Y.J. A Review of the Pharmacological Efficacy and Safety of Licorice Root from Corroborative Clinical Trial Findings. J. Med. Food 2020, 23, 12-20. [CrossRef]

254. Scaglione, F.; Cattaneo, G.; Alessandria, M.; Cogo, R. Efficacy and safety of the standardised Ginseng extract G115 for potentiating vaccination against the influenza syndrome and protection against the common cold [corrected]. Drugs Exp. Clin. Res. 1996, 22, 65-72.

255. Scaglione, F.; Weiser, K.; Alessandria, M. Effects of the Standardised Ginseng Extract G115®in Patients with Chronic Bronchitis. Clin. Drug Investig. 2001, 21, 41-45. [CrossRef]

256. Lee, C.S.; Lee, J.H.; Oh, M.; Choi, K.-M.; Jeong, M.R.; Park, J.D.; Kwon, D.Y.; Ha, K.C.; Park, E.O.; Lee, N.; et al. Preventive Effect of Korean Red Ginseng for Acute Respiratory Illness: A Randomized and Double-Blind Clinical Trial. J. Korean Med. Sci. 2012, 27, 1472-1478. [CrossRef] [PubMed]

257. Chuang, M.-L.; Wu, T.-C.; Wang, Y.-T.; Wang, Y.-C.; Tsao, T.C.Y.; Wei, J.C.-C.; Chen, C.-Y.; Lin, I.F. Adjunctive Treatment with Rhodiola Crenulata in Patients with Chronic Obstructive Pulmonary Disease-A Randomized Placebo Controlled Double Blind Clinical Trial. PLoS ONE 2015, 10, e0128142. [CrossRef] [PubMed]

258. Zhang, S.; Gao, W.; Xu, K.; Guo, Y.; Lin, S.; Xue, X.; Lu, G.; Li, N.; Liu, H.; Liu, W. Early use of Chinese drug rhodiola compound for patients with post-trauma and inflammation in prevention of ALI/ARDS. Zhonghua Wai Ke Za Zhi 1999, 37, 238-240. [PubMed]

259. Lu, W.S.Z.; Cao, X.W.S.F. Early use of Chinese drug rhodiola compound for patients with thoracic operation inprevention of ALI. Med. J. Natl. Defending Forces Northwest China 2004, 2.

260. Ahmed, M.; Henson, D.A.; Sanderson, M.C.; Nieman, D.C.; Zubeldia, J.M.; Shanely, R.A. Rhodiola rosea exerts antiviral activity in athletes following a competitive marathon race. Front. Nutr. 2015, 2, 24. [CrossRef]

261. Yu, L.; Qin, Y.; Wang, Q.; Zhang, L.; Liu, Y.; Wang, T.; Huang, L.; Wu, L.; Xiong, H. The efficacy and safety of Chinese herbal medicine, Rhodiola formulation in treating ischemic heart disease: A systematic review and meta-analysis of randomized controlled trials. Complementary Ther. Med. 2014, 22, 814-825. [CrossRef]

262. Lebedev, A.A. The effect of Schisandra seed tincture on morbidity rate among workers of Chirick shoe factory during the 1969 influenza epidemic. In Medicinal Products of the Far East; Brekhman, I.I., Fruentov, N.K., Eds.; Far East Branch of the USSR Academy of Science, Khabarovsk Medical Institute: Khabarovsk, USSR, 1970; pp. 115-119.

263. Lebedev, A.A. Schizandra seed tincture and dibazole as means of non-specific prophylaxis of acute respiratory infections during the peak of influenza at the beginning of 1969. Med. Zhurnal Uzb. 1971, 6, 70-72.

264. Pavlushchenko, E.V. Pneumonia in aged and old people in conditions of the monsoon climate of the southern Primorskij region. In New Data on Eleutherococcus and Other Adaptogens; Bulanov, A.E., Dardimov, I.V., Li, S.E., Eds.; Far East Branch of the USSR Academy of Science, Institute of Marine Biology: Vladivostok, USSR, 1981; pp. 119-122. 
265. Tandon, N.; Yadav, S.S. Safety and clinical effectiveness of Withania Somnifera (Linn.) Dunal root in human ailments. J. Ethnopharmacol. 2020, 255, 112768. [CrossRef]

266. Sandhu, J.S.; Shah, B.; Shenoy, S.; Chauhan, S.; Lavekar, G.S.; Padhi, M.M. Effects of Withania somnifera (Ashwagandha) and Terminalia arjuna (Arjuna) on physical performance and cardiorespiratory endurance in healthy young adults. Int. J. Ayurveda Res. 2010, 1, 144-149. [CrossRef]

267. Caceres, D.; Hancke, J.; Burgos, R.; Wikman, G. Prevention of common colds with Andrographis paniculata dried extract. A pilot double blind trial. Phytomedicine 1997, 4, 101-104. [CrossRef]

268. Gabrielian, E.S.; Shukarian, A.K.; Goukasova, G.I.; Chandanian, G.L.; Panossian, A.G.; Wikman, G.; Wagner, H. A double blind, placebo-controlled study of Andrographis paniculata fixed combination Kan Jang in the treatment of acute upper respiratory tract infections including sinusitis. Phytomedicine 2002, 9, 589-597. [CrossRef] [PubMed]

269. Kulichenko, L.L.; Kireyeva, L.V.; Malyshkina, E.N.; Wikman, G. A Randomized, Controlled Study of Kan Jang versus Amantadine in the Treatment of Influenza in Volgograd. J. Herb. Pharmacother. 2003, 3, 77-93. [CrossRef] [PubMed]

270. Melchior, J.; Spasov, A.A.; Ostrovskij, O.V.; Bulanov, A.E.; Wikman, G. Double-blind, placebo-controlled pilot and Phase III study of activity of standardized Andrographis paniculata Herba Nees extract fixed combination (Kan jang) in the treatment of uncomplicated upper-respiratory tract infection. Phytomedicine 2000, 7, 341-350. [CrossRef]

271. Spasov, A.A.; Ostrovskij, O.V.; Chernikov, M.V.; Wikman, G. Comparative controlled study of Andrographis paniculata fixed combination, Kan Jang®and an Echinacea preparation as adjuvant, in the treatment of uncomplicated respiratory disease in children. Phytother. Res. 2004, 18, 47-53. [CrossRef] [PubMed]

272. Anon. Periodic Safety Update Report for Kan Jang; Period Covered by this Report: From 23 November 2006 to 22 November 2009; Swedish Herbal Institute: Gothenburg, Sweden, 2010.

273. Cook, D.N.; Kang, H.S.; Jetten, A.M. Retinoic Acid-Related Orphan Receptors (RORs): Regulatory Functions in Immunity, Development, Circadian Rhythm, and Metabolism. Nucl. Recept. Res. 2015, 2, 101185. [CrossRef] [PubMed]

274. Jetten, A.M. Retinoid-Related Orphan Receptors (RORs): Critical Roles in Development, Immunity, Circadian Rhythm, and Cellular Metabolism. Nucl. Recept. Signal. 2009, 7, nrs.07003. [CrossRef]

275. Kojetin, D.J.; Burris, T.P. REV-ERB and ROR nuclear receptors as drug targets. Nat. Rev. Drug Discov. 2014, 13, 197-216. [CrossRef]

276. Pandi-Perumal, S.R.; BaHammam, A.S.; Brown, G.M.; Spence, D.W.; Bharti, V.K.; Kaur, C.; Hardeland, R.; Cardinali, D.P. Melatonin Antioxidative Defense: Therapeutical Implications for Aging and Neurodegenerative Processes. Neurotox. Res. 2013, 23, 267-300. [CrossRef]

277. Tarocco, A.; Caroccia, N.; Morciano, G.; Wieckowski, M.R.; Ancora, G.; Garani, G.; Pinton, P. Melatonin as a master regulator of cell death and inflammation: Molecular mechanisms and clinical implications for newborn care. Cell Death Dis. 2019, 10, 317. [CrossRef]

278. Arushanian, E.; Beйer, E. Pineal hormone melatonin is an universal adaptogenic agent. Uspekhi Fiziol. Nauk 2012, 43, 82 .

279. Maestroni, G.J.M. Melatonin and the Immune System Therapeutic Potential in Cancer, Viral Diseases, and Immunodeficiency States. In The Pineal Gland and Cancer: Neuroimmunoendocrine Mechanisms in Malignancy; Bartsch, C., Bartsch, H., Blask, D.E., Cardinali, D.P., Hrushesky, W.J.M., Mecke, D., Eds.; Springer: Berlin/Heidelberg, Germany, 2001; pp. 384-394. [CrossRef]

280. Arnao, M.B.; Hernández-Ruiz, J. Melatonin and its relationship to plant hormones. Ann. Bot. 2018, 121, 195-207. [CrossRef] [PubMed]

281. Fan, J.; Xie, Y.; Zhang, Z.; Chen, L. Melatonin: A Multifunctional Factor in Plants. Int. J. Mol. Sci. 2018, 19, 1528. [CrossRef] [PubMed]

282. Hardeland, R. Aging, Melatonin, and the Pro- and Anti-Inflammatory Networks. Int. J. Mol. Sci. 2019, $20,1223$. [CrossRef] [PubMed]

283. Nawaz, M.A.; Huang, Y.; Bie, Z.; Ahmed, W.; Reiter, R.J.; Niu, M.; Hameed, S. Melatonin: Current Status and Future Perspectives in Plant Science. Front. Plant. Sci. 2016, 6, 1230. [CrossRef]

284. Karasek, M. Melatonin, human aging, and age-related diseases. Exp. Gerontol. 2004, 39, 1723-1729. [CrossRef] [PubMed] 
285. Arnao, M.B.; Hernández-Ruiz, J. The physiological function of melatonin in plants. Plant. Signal. Behav. 2006, 1, 89-95. [CrossRef] [PubMed]

286. Chen, G.; Huo, Y.; Tan, D.-X.; Liang, Z.; Zhang, W.; Zhang, Y. Melatonin in Chinese medicinal herbs. Life Sci. 2003, 73, 19-26. [CrossRef]

287. Arnao, M.B.; Hernández-Ruiz, J. The potential of phytomelatonin as a nutraceutical. Molecules 2018, $23,238$. [CrossRef]

288. Manchester, L.C.; Tan, D.-X.; Reiter, R.J.; Park, W.; Monis, K.; Qi, W. High levels of melatonin in the seeds of edible plants: Possible function in germ tissue protection. Life Sci. 2000, 67, 3023-3029. [CrossRef]

289. Pérez-Llamas, F.; Hernández-Ruiz, J.; Cuesta, A.; Zamora, S.; Arnao, M.B. Development of a Phytomelatonin-Rich Extract from Cultured Plants with Excellent Biochemical and Functional Properties as an Alternative to Synthetic Melatonin. Antioxidants 2020, 9, 158. [CrossRef]

290. Andersen, L.P.; Werner, M.U.; Rosenkilde, M.M.; Harpsøe, N.G.; Fuglsang, H.; Rosenberg, J.; Gögenur, I. Pharmacokinetics of oral and intravenous melatonin in healthy volunteers. BMC Pharmacol. Toxicol. 2016, 17, 1-5. [CrossRef] [PubMed]

291. Zhou, Y.; Hou, Y.; Shen, J.; Huang, Y.; Martin, W.; Cheng, F. Network-based drug repurposing for novel coronavirus 2019-nCoV/SARS-CoV-2. Cell Discov. 2020, 6, 14. [CrossRef] [PubMed]

292. Anderson, G.; Reiter, R.J. Melatonin: Roles in influenza, Covid-19, and other viral infections. Rev. Med. Virol. 2020, 30, e2109. [CrossRef] [PubMed]

293. Shneider, A.; Kudriavtsev, A.; Vakhrusheva, A. Can melatonin reduce the severity of COVID-19 pandemic? Int. Rev. Immunol. 2020, 39, 153-162. [CrossRef] [PubMed]

294. Zhang, R.; Wang, X.; Ni, L.; Di, X.; Ma, B.; Niu, S.; Liu, C.; Reiter, R.J. COVID-19: Melatonin as a potential adjuvant treatment. Life Sci. 2020, 250, 117583. [CrossRef]

295. Huang, S.-H.; Liao, C.-L.; Chen, S.-J.; Shi, L.-G.; Lin, L.; Chen, Y.-W.; Cheng, C.-P.; Sytwu, H.-K.; Shang, S.-T.; Lin, G.-J. Melatonin possesses an anti-influenza potential through its immune modulatory effect. J. Funct. Foods 2019, 58, 189-198. [CrossRef]

296. Huang, S.-H.; Cao, X.-J.; Liu, W.; Shi, X.-Y.; Wei, W. Inhibitory effect of melatonin on lung oxidative stress induced by respiratory syncytial virus infection in mice. J. Pineal Res. 2010, 48, 109-116. [CrossRef]

297. Silvestri, M.; Rossi, G.A. Melatonin: Its possible role in the management of viral infections-a brief review. Ital. J. Pediatrics 2013, 39, 61. [CrossRef]

298. Ben-Nathan, D.; Maestroni, G.; Lustig, S.; Conti, A. Protective effects of melatonin in mice infected with encephalitis viruses. Arch. Virol. 1995, 140, 223-230. [CrossRef]

299. Bonilla, E.; Rodón, C.; Valero, N.; Pons, H.; Chacín-Bonilla, L.; Tamayo, J.G.; Rodríguez, Z.; Medina-Leendertz, S.; Añez, F. Melatonin prolongs survival of immunodepressed mice infected with the Venezuelan equine encephalomyelitis virus. Trans. R. Soc. Trop. Med. Hyg. 2001, 95, 207-210. [CrossRef]

300. Bonilla, E.; Valero, N.; Chacín-Bonilla, L.; Medina-Leendertz, S. Melatonin and viral infections. J. Pineal Res. 2004, 36, 73-79. [CrossRef] [PubMed]

301. Bonilla, E.; Valero-Fuenmayor, N.; Pons, H.; Chacin-Bonilla, L. Melatonin protects mice infected with Venezuelan equine encephalomyelitis virus. Cell. Mol. Life Sci. CMLS 1997, 53, 430-434. [CrossRef] [PubMed]

302. Nejati Moharrami, N.; Bjørkøy Tande, E.; Ryan, L.; Espevik, T.; Boyartchuk, V. ROR $\alpha$ controls inflammatory state of human macrophages. PLOS ONE 2018, 13, e0207374. [CrossRef] [PubMed]

303. Delerive, P.; Monté, D.; Dubois, G.; Trottein, F.; Fruchart-Najib, J.; Mariani, J.; Fruchart, J.-C.; Staels, B. The orphan nuclear receptor $\mathrm{ROR} \alpha$ is a negative regulator of the inflammatory response. EMBO Rep. 2001, 2, 42-48. [CrossRef]

304. Gold, M.J.; Antignano, F.; Halim, T.Y.F.; Hirota, J.A.; Blanchet, M.-R.; Zaph, C.; Takei, F.; McNagny, K.M. Group 2 innate lymphoid cells facilitate sensitization to local, but not systemic, TH2-inducing allergen exposures. J. Allergy Clin. Immunol. 2014, 133, 1142-1148.e1145. [CrossRef]

305. Halim Timotheus, Y.F.; MacLaren, A.; Romanish Mark, T.; Gold Matthew, J.; McNagny Kelly, M.; Takei, F. Retinoic-Acid-Receptor-Related Orphan Nuclear Receptor Alpha Is Required for Natural Helper Cell Development and Allergic Inflammation. Immunity 2012, 37, 463-474. [CrossRef]

306. Lo, B.C.; Gold, M.J.; Hughes, M.R.; Antignano, F.; Valdez, Y.; Zaph, C.; Harder, K.W.; McNagny, K.M. The orphan nuclear receptor ROR alpha and group 3 innate lymphoid cells drive fibrosis in a mouse model of Crohn's disease. Sci. Immunol. 2016, 1, eaaf8864. [CrossRef] 
307. Friesenhagen, J.; Viemann, D.; Börgeling, Y.; Schmolke, M.; Spiekermann, C.; Kirschnek, S.; Ludwig, S.; Roth, J. Highly Pathogenic Influenza Viruses Inhibit Inflammatory Response in Monocytes via Activation of Rar-Related Orphan Receptor RORa. J. Innate Immun. 2013, 5, 505-518. [CrossRef]

308. Yanuck, S.F.P.; Messier, H.J.; Fitzgerald, K.N. Evidence Supporting a Phased Immuno-physiological Approach to COVID-19 from Prevention through Recovery. Integr. Med. 2020, 19, 8-35.

309. Narimanian, M.; Badalyan, M.; Panosyan, V.; Gabrielyan, E.; Panossian, A.; Wikman, G.; Wagner, H. Impact of Chisan $®(A D A P T-232)$ on the quality-of-life and its efficacy as an adjuvant in the treatment of acute non-specific pneumonia. Phytomedicine 2005, 12, 723-729. [CrossRef] [PubMed]

(C) 2020 by the authors. Licensee MDPI, Basel, Switzerland. This article is an open access article distributed under the terms and conditions of the Creative Commons Attribution (CC BY) license (http://creativecommons.org/licenses/by/4.0/). 